Article

\title{
Investigating Molecular Mechanisms of Immunotoxicity and the Utility of ToxCast for Immunotoxicity Screening of Chemicals Added to Food
}

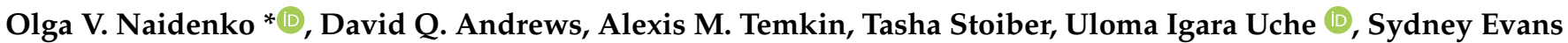 \\ and Sean Perrone-Gray
}

check for updates

Citation: Naidenko, O.V.; Andrews, D.Q.; Temkin, A.M.; Stoiber, T.; Uche, U.I.; Evans, S.; Perrone-Gray, S. Investigating Molecular Mechanisms of Immunotoxicity and the Utility of ToxCast for Immunotoxicity Screening of Chemicals Added to Food. Int. J. Environ. Res. Public Health 2021, 18, 3332. https:// doi.org/10.3390/ijerph18073332

Academic Editor: Jörg Lehmann

Received: 17 February 2021

Accepted: 15 March 2021

Published: 24 March 2021

Publisher's Note: MDPI stays neutral with regard to jurisdictional claims in published maps and institutional affiliations.

Copyright: (c) 2021 by the authors. Licensee MDPI, Basel, Switzerland. This article is an open access article distributed under the terms and conditions of the Creative Commons Attribution (CC BY) license (https:/ / creativecommons.org/licenses/by/ $4.0 /)$.
Environmental Working Group, 1436 U Street NW, Suite 100, Washington, DC 20009, USA; dandrews@ewg.org (D.Q.A.); alexis@ewg.org (A.M.T.); tstoiber@ewg.org (T.S.); uloma.uche@ewg.org (U.I.U.); sydney.evans@ewg.org (S.E.); sean@ewg.org (S.P.-G.)

* Correspondence: olga@ewg.org

\begin{abstract}
The development of high-throughput screening methodologies may decrease the need for laboratory animals for toxicity testing. Here, we investigate the potential of assessing immunotoxicity with high-throughput screening data from the U.S. Environmental Protection Agency ToxCast program. As case studies, we analyzed the most common chemicals added to food as well as per- and polyfluoroalkyl substances (PFAS) shown to migrate to food from packaging materials or processing equipment. The antioxidant preservative tert-butylhydroquinone (TBHQ) showed activity both in ToxCast assays and in classical immunological assays, suggesting that it may affect the immune response in people. From the PFAS group, we identified eight substances that can migrate from food contact materials and have ToxCast data. In epidemiological and toxicological studies, PFAS suppress the immune system and decrease the response to vaccination. However, most PFAS show weak or no activity in immune-related ToxCast assays. This lack of concordance between toxicological and high-throughput data for common PFAS indicates the current limitations of in vitro screening for analyzing immunotoxicity. High-throughput in vitro assays show promise for providing mechanistic data relevant for immune risk assessment. In contrast, the lack of immune-specific activity in the existing high-throughput assays cannot validate the safety of a chemical for the immune system.
\end{abstract}

Keywords: immunotoxicology; multi-omics approaches in immunotoxicology; immunotoxic aspects of food additives; high-throughput screening; ToxCast; food additive; food contact substance; tertbutylhydroquinone; per- and polyfluoroalkyl substances

\section{Introduction}

The immune system is one of the targets of chemical toxicity. Immune toxicity has been reported for a variety of substances, including arsenic compounds [1], chlorinated solvents [2], pesticides [3], and per- and polyfluoroalkyl substances [4], and the developing immune system is more susceptible to the harmful impact of chemical exposures compared to the adult immune system [5-8]. Immunotoxicology as a field has existed since the 1970s [9], and expert groups have published recommendations for conducting immune toxicity assessments [10,11]. Immunotoxicity is defined as the maladaptive functioning of the immune system following exposure to a xenobiotic substance. This phenomenon includes the loss of function (immunosuppression); excessive, damaging immune reactions (immunoenhancement); and alterations in the immune response that may be permanent or reversible (immunomodulation). The effect of a substance on the immune system depends on multiple factors such as route and duration of exposure and the toxicity mechanism. Immunotoxic effects can manifest in different ways, including lower antibody levels following vaccination, autoimmune symptoms, or systemic inflammation [12,13].

The recognition of the immune system's susceptibility to environmental contaminants led to the development of assays that can evaluate chemicals for their immunotoxic po- 
tential [14]. Immunotoxicity analyses can evaluate histopathology and weight of immune system organs, lymphocyte counts, serum immunoglobulin levels, cell-mediated immune response, antibody production, natural killer (NK) cell function, and other functions [10]. Observational immunotoxicity measurements, such as analyses of the number and relative frequency of specific immune cell types, cannot provide mechanistic data on how the immune system is affected by a chemical substance. Functional tests such as T-cell-dependent antibody response assays and cytotoxicity assays advance immunotoxicity assessment one step further. Finally, the host resistance assays that measure immune defense against infectious agents have been considered the gold standard of immunotoxicity testing [15]. Given the complexity of the immune system, no single assay may be sufficient to determine immunotoxicity, and a combination of analyses for different immunological endpoints is likely needed for predicting immunotoxicity [12]. Mechanistic data, where available, can confirm the findings from other lines of evidence, such as studies in laboratory animals [13].

Despite the availability of testing methods for immunotoxicity, such testing has not been a priority in chemical risk assessment. The Organisation for Economic Co-operation and Development and European Union chemical test guidelines include an assessment of immune system parameters (such as lymphoid organ weights, hematology, and histopathology evaluation) as a part of standard oral 28-day and 90-day toxicity studies in laboratory animals, but do not require a systematic analysis of immunotoxicity for manufactured chemicals or contaminants [16]. The U.S. Environmental Protection Agency published immunotoxicity testing guidelines for pesticides in 1998, but later stated that this testing requirement can be waived $[17,18]$. The U.S. EPA Design for the Environment Program criterion document on hazard evaluation of chemical alternatives lists immunotoxicity among the less commonly considered toxicity endpoints [19].

New approach methodologies, such as high-throughput screening and omics technologies (genomics, transcriptomics, proteomics, and metabolomics), hold the promise of generating new data helpful for chemical risk assessment, including immunotoxicity assessment $[20,21]$. The U.S. EPA ToxCast program integrates high-throughput screening assays relevant to diverse toxicological endpoints, organ systems, and disease processes [22-25]. Two recent studies have classified ToxCast assays relevant to induction of chronic inflammation, an immune-mediated process [26,27]. However, a systematic evaluation of immune-relevant ToxCast assays is still needed. Due to the diversity of molecular pathways and orchestration of multiple cell types and tissues involved in the immune response, translation from high throughput data or animal-free models to toxicological endpoints relevant to the immune system remains a challenge [28].

Here we investigate whether the data generated under the U.S. EPA ToxCast program can be used for immunotoxicity screening. We focus on substances present in food, which include direct food additives and substances that can migrate into packaged food from food contact materials.

\section{Materials and Methods}

\subsection{Data-Mining Strategy for the Identification of Immune-Relevant High-Throughput Assays}

Our analysis incorporates data from the U.S. EPA ToxCast CompTox Dashboard (https:/ / comptox.epa.gov/ dashboard, accessed on 24 September 2020) and the Comparative Toxicogenomics Database (http:/ / ctdbase.org, accessed on 24 September 2020). The Comparative Toxicogenomics Database, developed by researchers from MDI Biological Laboratory (Salisbury Cove, ME, USA) and North Carolina State University (Raleigh, NC, USA), is a manually curated database based on peer-reviewed literature listed in PubMed [29,30]. Interactions for the phenotype described as "immune system process" were retrieved from the Comparative Toxicogenomics Database website in September 2020.

ToxCast datasets were directly downloaded from the U.S. EPA CompTox Chemicals Dashboard, and all ToxCast information cited here represents the data viewable on the U.S. EPA website in September 2020. The ToxCast program comprises hundreds of highthroughput assays developed under different assay platforms, including both cell-free 
and cell-based assays [31]. Assay results for individual chemicals are classified by the ToxCast as hit-call "active" or "inactive" (meeting or not meeting dose-response criteria). Modeled $\mathrm{AC}_{50}$ values (activity concentration at $50 \%$ maximal activity) are viewable in the CompTox Dashboard. Each chemical is also assigned a "cytotoxicity limit", a calculated value that reflects the overall cytotoxicity of an individual chemical in ToxCast assays [31]. The cytotoxicity limit does not indicate the cytotoxicity of a substance in a specific assay, and data from assays with $\mathrm{AC}_{50}$ values above the calculated cytotoxicity limit may be biologically relevant [27].

ToxCast data modeling published on the U.S. EPA CompTox Dashboard includes an assignment of data quality flags to assays such as "less than $50 \%$ efficacy", "only highest [concentration] above baseline", "borderline active", "noisy data", and other flags. Based on the manual review of ToxCast assay charts for the chemicals included in this study, we focused on two types of assays with the strongest evidence for response specificity: assays with no data quality flags and assays with only one data quality flag, "less than $50 \%$ efficacy".

Among the ToxCast assays activated by the case study compounds, we identified the assays that focused on a specific gene target (thus excluding assays that measure cytotoxicity, proliferation, or viability) and reviewed the function of each gene according to the information listed in the NCBI Gene database (https:/ / www.ncbi.nlm.nih.gov/gene/, accessed on 24 September 2020) and PubMed database. We classified ToxCast assays as relevant to the immune system based on the involvement of their target genes or proteins in innate and adaptive immune responses, as reported in the peer-reviewed literature and gene function summaries.

\subsection{Identification of Case Study Compounds}

\subsubsection{Direct Food Additives}

Karmaus et al. [32,33] examined the universe of chemicals allowed in food in the United States for which data are available in the U.S. EPA ToxCast and identified a set of 556 chemicals directly added to food for functional purposes and 339 chemicals that may migrate to food from packaging, processing, or cleaning chemicals. Some chemicals in the above subset may be approved for use both as direct additives and in food packaging. We started with the list of 556 direct food additives defined by Karmaus et al. [33] along with the addition of butylated hydroxyanisole, a direct food additive used as an antioxidant preservative [34]. To identify the additives used most commonly in the U.S. food supply, chemical names for the 557 direct additives from Karmaus et al. [33] were matched to labels for over 120,000 packaged food and beverage products sold in U.S. grocery stores between 2018 and 2020. The label data analyzed by our research group was provided by Label Insight, a leading source of validated metadata for product attributes. Label Insight's label data coverage exceeds $80 \%$ of consumer product goods sold in the United States (https:/ / www.labelinsight.com/about, accessed on 24 September 2020).

\subsubsection{Indirect Additives: Per- and Polyfluoroalkyl Substances}

For our analysis of indirect food additives, we narrowed our scope to the class of per- and polyfluoroalkyl substances (PFAS), chemicals used in food packaging and with known immunotoxicity for some members of the class [35]. To identify which PFAS were reported to migrate to food, we searched PubMed for relevant publications using the search query ("PFAS" OR "fluorotelomer" OR "fluorochemical" OR "perfluoroalkyl" OR "perfluorinated" OR "polyfluorinated" or "PFOA" or "perfluorochemicals" OR "fluorinated" OR "FTOH") AND ("migration" OR "release" or "extractable") AND "food". In addition, the references within relevant publications were also reviewed for inclusion in our analysis. PFAS-based food contact substances were also reviewed in the U.S. Food and Drug Administration (U.S. FDA) database of Packaging \& Food Contact Substances [36]. 


\section{Results}

\subsection{Identification of Case Study Compounds}

To identify the most common food additives for which high throughput ToxCast data are available, we matched the list of 557 direct additives [33] to ingredient labels of products sold in the United States in 2018-2020. From this group, 81 substances were identified on ingredient labels, and we ranked the additives by frequency of use. Among the remaining additives that could not be matched to ingredient labels, the majority (430 additives) are flavoring substances, which typically appear on the label under the name of artificial or natural flavors. Due to lack of disclosure for flavoring ingredients, we were unable to assess either their frequency of use or estimate dietary exposure. Eighteen additives that were present in less than 10 product labels were not included in further review (benzyl benzoate, betaine, butylene glycol, butylparaben, butyric acid, citral, dioctyl sodium sulphosuccinate, menthol, myristic acid, oleic acid, phenoxyethanol, piperine, resveratrol, sodium iodide, tannic acid, terpineol, theobromine, xylose). The 63 substances present on labels of more than 10 products were categorized by their functional class (Figure 1) and included in subsequent analyses.

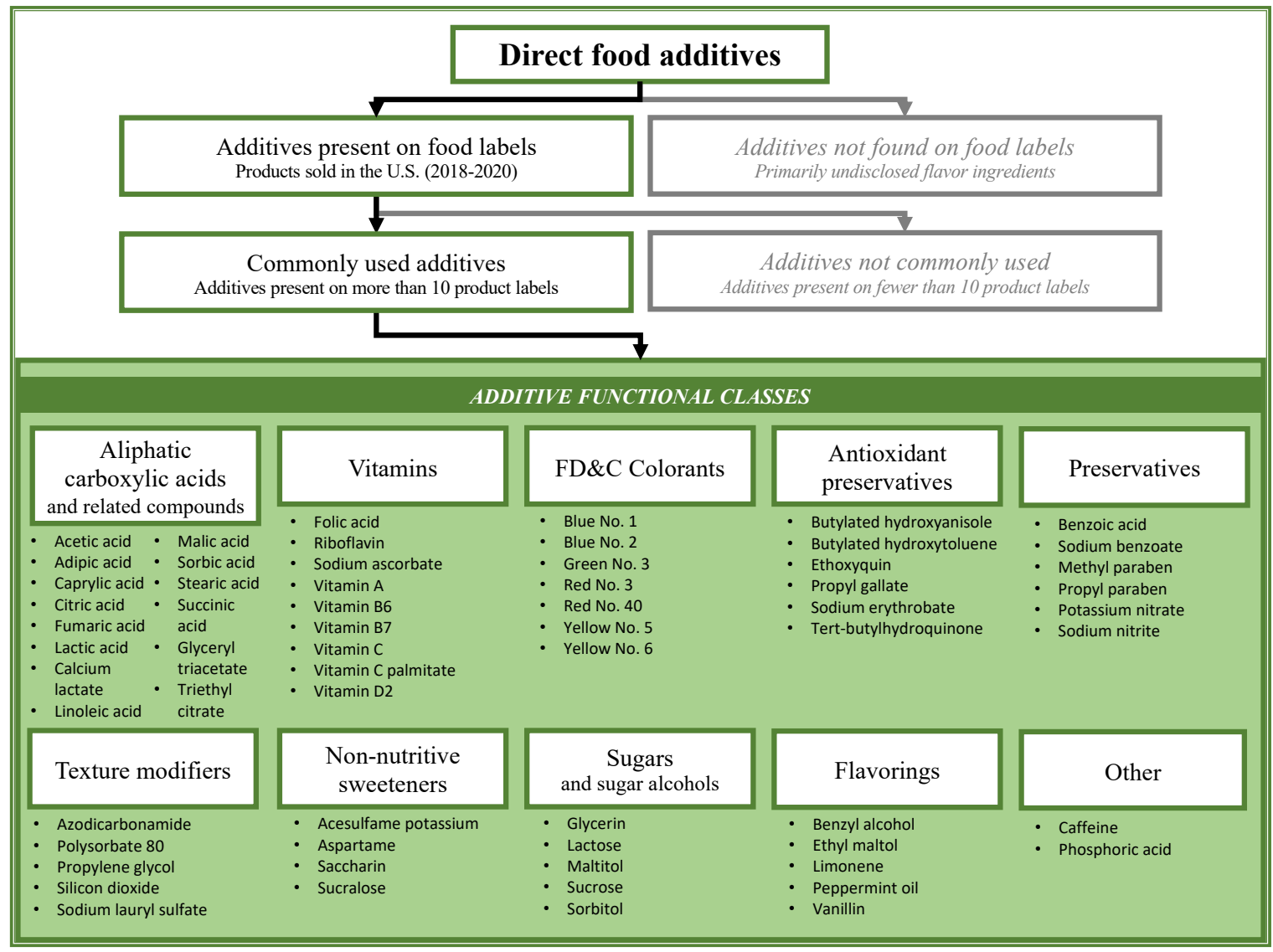

Figure 1. Flow diagram for identification of direct additives included in this study. Initial group of direct food additives analyzed in this study was defined in a publication by Karmaus et al. [33].

In contrast to direct food additives, prioritization of indirect food additives by frequency of exposure is challenging, since these substances are not disclosed on the ingredient label. The U.S. FDA Inventory of Effective Food Contact Substance Notifications lists 1493 compounds that have been approved for use in the United States as food contact substances (with 71 of those listed as replaced) as of September 2020 [36]. Based on the U.S. FDA food contact substances inventory data from the past 10 years, on average, around 65 new food contact materials receive U.S. FDA approval every year. For the case study on indirect 
food additives, we focused on the family of per- and polyfluoroalkyl substances (PFAS) that have been used in food contact materials for decades $[37,38]$ and are associated with toxicity to the immune system [35]. The PFAS-based materials have been used in sealing gaskets in food processing equipment, repeat-use plastics, non-stick coatings on cookware, and oil- and water-resistant coatings on paper and cardboard food packaging [35]. These PFAS materials, typically polymers, can contain and release monomeric PFAS as well as PFAS fragmentation products [39]. A recent study based on the data from the U.S. National Health and Nutrition Examination Survey reported an association between PFAS concentrations in the body and consumption of meals whose packaging may contain PFAS, such as fast foods, pizzas, and popcorn [40]. Some examples of PFAS structures that have been used in food contact materials are depicted in Figure 2.

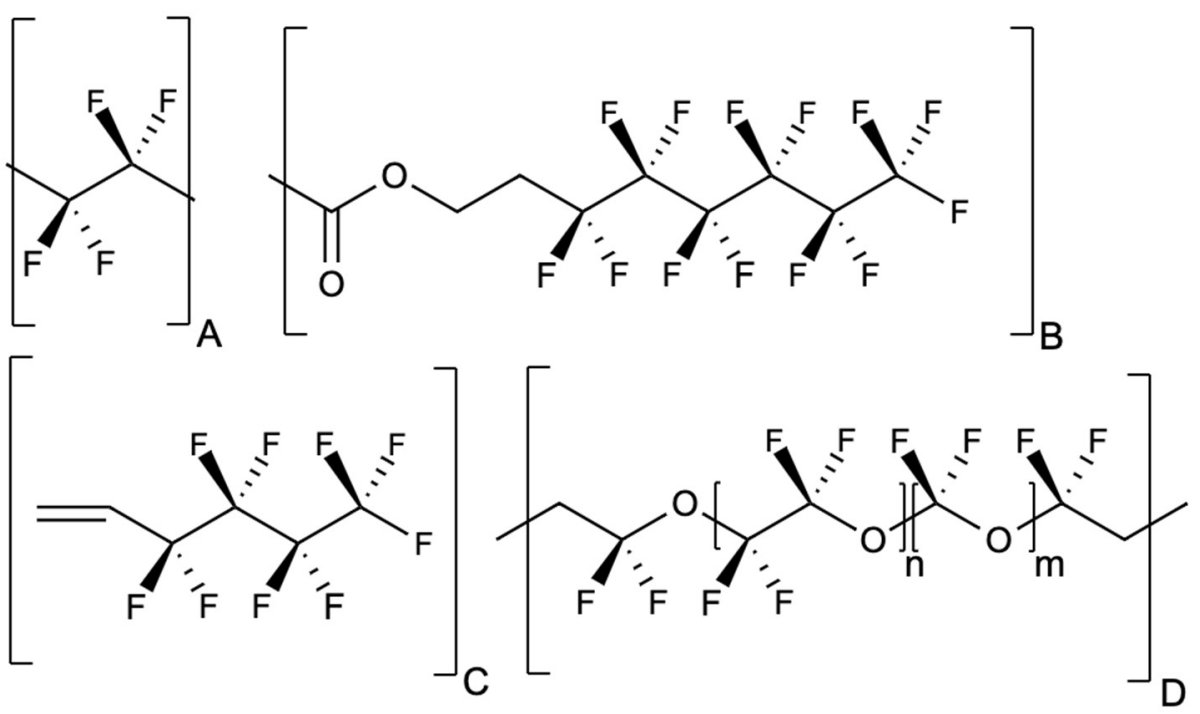

Figure 2. Structures of several PFAS food contact materials. (A) shows the structure of polytetrafluoroethylene or PTFE, used for coatings on cookware, pans, and utensils. (B) shows the 6:2 fluorotelomer structure present in multiple food contact substances approved by the U.S. FDA since 2008, which are undergoing the voluntary phase-out starting in July 2020 [41]. (C) shows the fluorinated monomer ingredient that, in combination with perfluoroethylene and ethylene, is used to manufacture a PFAS-based terpolymer approved in 2018 (U.S. FDA food contact notification approval No. 1914). (D) shows the fluorinated section of a perfluoroether polymer approved in 2010 (U.S. FDA food contact notification approval No. 962).

To identify PFAS species reported to end up in food from food contact materials, we compiled information from the studies of PFAS migration based on publications in PubMed (findings summarized in Appendix A Table A1). Across all studies identified, PFAS migration varied depending on the type of food and its composition, with fatty materials typically enabling the greatest migration of PFAS from food packaging to food materials or food simulators, and short-chain PFAS migrating more readily compared to long-chain PFAS, a finding consistent with other reports in the literature [42]. Further, given that the laboratory methods are generally limited to detecting PFAS for which analytical standards are available, it is likely that some portion of PFAS that may migrate to food, by weight or types of compounds, was missed. In 2020, the U.S. FDA announced the voluntary phase-out of the group of food contact substances based on 6:2 fluorotelomers (Figure 2B), due to uncertainty about public health risks of these compounds [41]. 


\subsection{Identification of ToxCast Active Assays}

Of the 22 unique PFAS identified in migration studies (Appendix A Table A1), nine had ToxCast data for the specific compounds or their salts (Table 1). These PFAS and the 63 direct additives were selected for further review (Table 2). Assay coverage in ToxCast varied from 238 assays for lithium perfluorooctanesulfonate and 250 assays for butylated hydroxyanisole to over 1000 assays for PFOA and PFOS. For our initial analysis, we included the ToxCast assays that were classified in the U.S. EPA CompTox Dashboard as "active" and that had modeled $\mathrm{AC}_{50}$ values (half-maximal activity) below the calculated cytotoxicity limit for the individual substance.

Table 1. Number of ToxCast assays for per- and polyfluoroalkyl substances (PFAS) with the half-maximal activity concentration $\left(\mathrm{AC}_{50}\right)$ below the cytotoxicity limit.

PFAS Reported to Migrate to Food, with CAS Numbers

Perfluorooctanesulfonic acid (1763-23-1)

Perfluoroundecanoic acid (2058-94-8)

Perfluorooctanoic acid (335-67-1)

Perfluorohexanoic acid (307-24-4)

Perfluorodecanoic acid (335-76-2)

Potassium perfluorooctanesulfonate (2795-39-3)

Ammonium perfluorooctanoate (3825-26-1)

Perfluorononanoic acid (375-95-1)

Perfluoroheptanoic acid (375-85-9)

6:2 fluorotelomer alcohol (647-42-7)

8:2 fluorotelomer alcohol (678-39-7)

6:2 fluorotelomer methacrylate (2144-53-8)

Lithium perfluorooctanesulfonate (29457-72-5)
Number of Assays with Half-Maximal Activity Concentration $\left(\mathrm{AC}_{50}\right)<$ Cytotoxicity Limit

Note: Based on ToxCast data publicly available in September 2020. This table includes assays without any data quality flags and assays with a single data quality flag, "less than $50 \%$ efficacy".

Table 2. Number of ToxCast assays for direct food additives with the half-maximal activity concentration $\left(\mathrm{AC}_{50}\right)$ below the cytotoxicity limit identified in Figure 1.

\begin{tabular}{|c|c|}
\hline Direct Food Additives & $\begin{array}{l}\text { Number of Assays with Half-Maximal Activity } \\
\text { Concentration }\left(\mathrm{AC}_{50}\right)<\text { Cytotoxicity Limit }\end{array}$ \\
\hline Tert-butylhydroquinone (TBHQ) & 58 \\
\hline FD\&C Red No. 3 (erythrosine) & 46 \\
\hline Propyl paraben & 23 \\
\hline Propyl gallate & 21 \\
\hline $\begin{array}{l}\text { Ethoxyquin, FD\&C Blue No. 1, folic acid, sodium lauryl sulfate, } \\
\text { sorbic acid, vitamin D2 }\end{array}$ & $11-16$ \\
\hline $\begin{array}{c}\text { Acetic acid, caprylic acid, FD\&C Green No. 3, maltol, methyl paraben, } \\
\text { sodium ascorbate, stearic acid, triethyl citrate, vitamin A }\end{array}$ & $6-10$ \\
\hline $\begin{array}{l}\text { Acesulfame potassium, adipic acid, ascorbyl palmitate, aspartame, } \\
\text { azodicarbonamide, benzoic acid, benzyl alcohol, butylated } \\
\text { hydroxytoluene, caffeine, calcium lactate, citric acid, ethyl maltol, } \\
\text { FD\&C Red No. 40, FD\&C Yellow No. 5, FD\&C Yellow No. 6, fumaric } \\
\text { acid, glycerin, glyceryl triacetate, limonene, linoleic acid, malic acid, } \\
\text { peppermint oil, phosphoric acid, potassium nitrate, propylene glycol, } \\
\text { riboflavin, saccharin, silicon dioxide, sodium erythorbate, sodium } \\
\text { nitrite, sorbitol, sucralose, sugar, vanillin, vitamin B6, vitamin C }\end{array}$ & $1-5$ \\
\hline $\begin{array}{l}\text { Butylated hydroxyanisole, FD\&C Blue No. 2, lactic acid, lactose, } \\
\text { polysorbate } 80 \text {, sodium benzoate, succinic acid, vitamin B7 }\end{array}$ & 0 \\
\hline
\end{tabular}

Note: Based on ToxCast data publicly available in September 2020. This table includes assays without any data quality flags and assays with a single data quality flag, "less than $50 \%$ efficacy". 
Among PFAS listed in Table 1, perfluoroundecanoic acid (PFUnDA), perfluorooctanesulfonic acid (PFOS), and perfluorooctanoic acid (PFOA) had the highest number of active ToxCast assays. Among direct food additives, three structurally related preservatives, tertbutylhydroquinone (TBHQ), propyl gallate, and propyl paraben, as well as food colorant FD\&C Red 3 (also called erythrosine) had the greatest number of active assays with good data quality and $\mathrm{AC}_{50}$ below their cytotoxicity limits, suggesting their broad biological activity in the high-throughput assays (Table 2). The substances with the highest number of active assays were reviewed for potential immune system impacts.

\subsection{Identification of Immune-Specific Interactions in the Comparative Toxicogenomics Database}

To query whether immune-relevant effects for these food additives were reported by prior studies, we reviewed the chemical-phenotype interactions for each substance identified in Tables 1 and 2 by searching the Comparative Toxicogenomics Database [29] under "immune system process" and substance name. We also queried PubMed with a search query of "Substance name AND T cell OR B cell OR Natural Killer OR immune OR immunotoxicity". References for the immune system interactions listed in the Comparative Toxicogenomics Database were manually reviewed and cross-checked against the studies identified from PubMed to confirm that the studies listed in the Comparative Toxicogenomics Database examined the direct effects of a substance on the immune-related parameters and functions.

Vitamins showed multiple phenotype interactions related to the "immune system process" in the Comparative Toxicogenomics Database as well as numerous related publications in PubMed. This result was expected, since vitamins are essential for the immune system and other biological processes. From the rest of the direct additive group, three substances had "immune system process" interactions in the Comparative Toxicogenomics Database: sodium lauryl sulfate (two interactions), TBHQ (12 interactions), and silicon dioxide (89 interactions from studies of immune-mediated inflammatory responses following inhalation exposure to silica and related materials). Among the PFAS, PFOA had 35 recorded interactions for "immune system process", and PFOS had three.

A limited number or the lack of interactions in the Comparative Toxicogenomics Database does not mean that the substance does not affect a particular activity because testing might not have been done to assess that endpoint, or because the relevant studies, such as testing conducted by government agencies or chemical manufacturers, may not be included in the database. For example, Rice et al. reported the adverse effects of PFHxA and 6:2 FTOH on the immune system [43]. However, these compounds do not have any immune interactions in the Comparative Toxicogenomics Database. On the other hand, prior studies reported that TBHQ changes multiple immune parameters [44-46] and that PFOA suppresses the immune system and decreases antibody response to vaccines [47], and the Comparative Toxicogenomics Database documents immune-related interactions for both substances.

\subsection{Analysis of Immune-Related Assays within ToxCast}

We reviewed the active ToxCast assays for all compounds included in this study and observed that food colorant FD\&C Red 3, antioxidant preservative TBHQ, and perfluoroundecanoic acid all showed activity towards multiple immune-related gene targets (Table 3). The targets included secreted proteins involved in cellular communication within the immune system (chemokines, cytokines, and growth factors); immune cell surface receptors (transmembrane proteins CD38, CD40, CD69, as well as leukotriene and prostaglandin receptors); and cell adhesion molecules that mediate the interaction between leukocytes and other cell types (E selectin, P selectin, ICAM1, and VCAM1). These proteins mediate the immune cell cross-talk and the orchestration of the innate and adaptive response against pathogens. 
Table 3. Immune targets in ToxCast assays affected by tert-butylhydroquinone, FD\&C Red 3, and several per- and polyfluoroalkyl substances.

\begin{tabular}{|c|c|c|c|c|c|c|c|c|}
\hline Gene Name and Function & ToxCast Assay Name & TBHQ & FD\&C Red 3 & PFOS & PFOA & PFNA & PFDA & PFUnDA \\
\hline $\begin{array}{c}\text { CCL2 (chemokine (C-C motif) ligand 2) } \\
\text { Chemokine with chemotactic activity for monocytes } \\
\text { and basophils }\end{array}$ & $\begin{array}{c}\text { BSK_3C_MCP1_down } \\
\text { BSK_CASM3C_MCP1_down } \\
\text { BSK_KF3CT_MCP1_down } \\
\text { BSK_LPS_MCP1_down } \\
\text { BSK_SAg_MCP1_down }\end{array}$ & $\begin{array}{l}2 \\
d\end{array}$ & $\begin{array}{l}2 \\
2 \\
2 \\
2\end{array}$ & & & & $\checkmark$ & $\checkmark$ \\
\hline $\begin{array}{l}\text { CCL26 (chemokine (C-C motif) ligand 26) } \\
\text { Chemokine with chemotactic activity for eosinophils } \\
\text { and basophils }\end{array}$ & BSK_4H_Eotaxin3_down & $\checkmark$ & & & & & & \\
\hline $\begin{array}{c}\text { CD40 molecule Transmembrane receptor expressed on } \\
\text { antigen-presenting cells }\end{array}$ & $\begin{array}{l}\text { BSK_LPS_CD40_down } \\
\text { BSK_SAg_CD40_down }\end{array}$ & $\begin{array}{l}2 \\
\checkmark \\
\end{array}$ & & & & & & \\
\hline $\begin{array}{l}\text { CD69 molecule } \\
\text { Transmembrane receptor expressed on activated T cells and } \\
\text { NK cells }\end{array}$ & BSK_SAg_CD69_down & $\checkmark$ & & & & & & \\
\hline $\begin{array}{l}\text { CSF1 (macrophage colony-stimulating factor) Cytokine that } \\
\text { controls the differentiation and function of macrophages }\end{array}$ & $\begin{array}{l}\text { BSK_hDFCGF_MCSF_down } \\
\text { BSK_LPS_MCSF_down }\end{array}$ & $\checkmark$ & $s$ & & & & & $\checkmark$ \\
\hline $\begin{array}{l}\text { CXCL8 (chemokine (C-X-C motif) ligand } 8 \text { ) Chemokine } \\
\text { secreted by macrophages, neutrophils, eosinophils, and T cells }\end{array}$ & $\begin{array}{l}\text { BSK_hDFCGF_IL8_down } \\
\text { BSK_LPS_IL8_down } \\
\text { BSK_SAg_IL8_down }\end{array}$ & $\begin{array}{l}2 \\
2 \\
d\end{array}$ & & & & & & $\checkmark$ \\
\hline $\begin{array}{l}\text { CXCL9 (chemokine (C-X-C motif) ligand 9) } \\
\text { Chemokine involved in immune regulation and } \\
\text { inflammatory processes }\end{array}$ & $\begin{array}{l}\text { BSK_BE3C_MIG_down } \\
\text { BSK_hDFCGF_MIG_down } \\
\text { BSK_SAg_MIG_down }\end{array}$ & $\checkmark$ & & & & & $\checkmark$ & $s$ \\
\hline $\begin{array}{l}\text { HLA-DRA (major histocompatibility complex class II) } \\
\text { Antigen-presenting molecule }\end{array}$ & $\begin{array}{l}\text { BSK_3C_HLADR_down } \\
\text { BSK_BE3C_HLADR_down }\end{array}$ & & $s$ & $\checkmark$ & & & $\checkmark$ & $\checkmark$ \\
\hline $\begin{array}{l}\text { ICAM1 (intercellular adhesion molecule 1) } \\
\text { Cell adhesion molecule }\end{array}$ & BSK_KF3CT_ICAM1_down & & & & & & & $\checkmark$ \\
\hline $\begin{array}{l}\text { IL-1 } \alpha \text { (Interleukin- } 1 \text {, alpha) } \\
\text { Cytokine produced by macrophages }\end{array}$ & $\begin{array}{l}\text { BSK_BE3C_IL1a_down } \\
\text { BSK_KF3CT_IL1a_down } \\
\text { BSK_LPS_IL1a_down }\end{array}$ & $\checkmark$ & 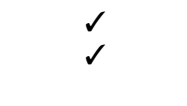 & & & & $\checkmark$ & 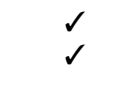 \\
\hline
\end{tabular}


Table 3. Cont.

\begin{tabular}{|c|c|c|c|c|c|c|c|c|}
\hline Gene Name and Function & ToxCast Assay Name & TBHQ & FD\&C Red 3 & PFOS & PFOA & PFNA & PFDA & PFUnDA \\
\hline $\begin{array}{l}\text { LTB4R (leukotriene B4 receptor) } \\
\text { Transmembrane receptor on immune cells }\end{array}$ & NVS_GPCR_gLTB4 & & & & $\checkmark$ & & $\checkmark$ & $\checkmark$ \\
\hline $\begin{array}{l}\text { E-selectin } \\
\text { Cell adhesion molecule }\end{array}$ & $\begin{array}{l}\text { BSK_LPS_Eselectin_down } \\
\text { BSK_SAg_Eselectin_down }\end{array}$ & $\begin{array}{l}2 \\
s\end{array}$ & $\checkmark *$ & & & & & \\
\hline $\begin{array}{c}\text { P-selectin } \\
\text { Cell adhesion molecule }\end{array}$ & BSK_4H_Pselectin_down & $\checkmark$ & & & & & & \\
\hline $\begin{array}{c}\text { Prostaglandin E receptor } 2 \\
\text { Transmembrane receptor on immune cells }\end{array}$ & BSK_LPS_PGE2_down & $\checkmark$ & $\checkmark$ & & & & & \\
\hline $\begin{array}{l}\text { TGF- } \beta 1 \text { (transforming growth factor, beta 1) } \\
\text { Growth factor that regulates immune responses }\end{array}$ & $\begin{array}{l}\text { BSK_BE3C_TGFb1_down } \\
\text { BSK_KF3CT_TGFb1_down }\end{array}$ & $\checkmark$ & $\begin{array}{l}2-1 \\
\checkmark \\
\checkmark\end{array}$ & & & & $\checkmark$ & $\begin{array}{l}2-1 \\
\checkmark \\
\checkmark\end{array}$ \\
\hline $\begin{array}{c}\text { TNF (tumor necrosis factor) } \\
\text { Pro-inflammatory cytokine primarily secreted by macrophages }\end{array}$ & BSK_LPS_TNFa_down & $\checkmark$ & & & & & & \\
\hline $\begin{array}{l}\text { VCAM1 (vascular cell adhesion molecule 1) Cell } \\
\text { adhesion molecule }\end{array}$ & $\begin{array}{c}\text { BSK_3C_VCAM1_down } \\
\text { BSK_4H_VCAM1_down } \\
\text { BSK_hDFCGF_VCAM1_down } \\
\text { BSK_LPS_VCAM1_down }\end{array}$ & $\begin{array}{l}2 \\
2 \\
2 \\
2\end{array}$ & & & & & & $\checkmark$ \\
\hline
\end{tabular}

Note: * This assay had one data quality flag indicating "noisy data". 
Among the assays listed in Table 3, all but one come from the BioSeek assay platform in Toxcast. This high-throughput screening platform is based on primary human cells, and individual BioSeek assays may include endothelial cells, peripheral blood mononuclear cells, bronchial epithelial cells, or fibroblasts [48]. The BioSeek assays use antibodies to detect either increase (up) or decrease (down) in target protein expression [48]. The direction of the BioSeek assays affected by TBHQ, FD\&C Red 3, and PFUnDA was "down", indicating a decrease in the cell surface expression of target proteins. Since the BioSeek assay platform uses human cells, substance activity in these assays suggests potential relevance for the human immune system.

Perfluorodecanoic acid (PFDA) was active in some of the same immune-target assays as PFUnDA (Table 3). Surprisingly, PFOA, PFOS, and perfluorononanoic acid (PFNA) did not show strong activity. PFNA affected one assay targeting cytokine CXCL10. PFOS affected two targets, CXCL10 and HLA-DR $\alpha$, major histocompatibility complex class II antigen-presenting molecule. PFOA, a well-studied PFAS with confirmed suppressive effects on the immune system, was weakly active in one immune-related assay, an assay targeting leukotriene B4 receptor, a transmembrane receptor involved in immune response and inflammation. Previous studies reported PFOA activity in ToxCast assays targeting estrogen receptor and peroxisome proliferator-activated receptors [26,49], indicating that ToxCast can identify active assays for this substance. No active assays for immunerelated targets were identified for other PFAS listed in Table 1 (perfluoroheptanoic acid, perfluorohexanoic acid, 6:2 fluorotelomer alcohol, and 8:2 fluorotelomer alcohol).

Finally, we identified the activity of TBHQ, FD\&C Red 3, PFDA, and PFUnDA in a subset of assays targeting proteins involved in extracellular matrix remodeling, coagulation, and fibrinolysis, processes that are involved in innate and adaptive immune response, inflammation and host defense (Table 4). For this group of targets, FD\&C Red 3 showed activity in most assays, followed by PFUnDA, TBHQ, and PFDA. PFOS affected the expression of one target, matrix metalloprotease 9. No other PFAS in our study affected the ToxCast targets listed in Table 4.

The observed activity of TBHQ and PFUnDA in immune-specific ToxCast assays is consistent with the research literature. TBHQ has been reported to affect different immune system parameters and functions [44-46]. The immunosuppressive effects of PFUnDA have been reported in epidemiological studies [50,51], consistent with data for other PFAS. In contrast, the activity of FD\&C Red 3 in assays with immune-specific targets was unexpected. No immune system process interactions were identified for this synthetic food colorant in the Comparative Toxicogenomics Database. Similarly, we could not identify studies in PubMed that reported immune system effects of FD\&C Red 3. Given that this compound is active in a subset of immune-targeted assays in ToxCast, it would be important to test FD\&C Red 3 in a standard panel of immunotoxicity assays.

TBHQ was also active in the ToxCast assays measuring the activity of transcription factors Nrf2 (nuclear factor, erythroid 2-like 2), aryl hydrocarbon receptor, and glucocorticoid receptor (Table 5). Prior studies reported that TBHQ effects are mediated via Nrf2, a transcription factor that regulates genes involved in antioxidant response, injury, and inflammation [52,53], and also via aryl hydrocarbon receptor (AhR) [54,55]. Aryl hydrocarbon receptor mediates cellular responses to a variety of xenobiotic substances and is now known to play an important regulatory role in the immune system [56]. The TBHQ-related activation of Nrf2 and AhR in ToxCast assays supports the specificity of TBHQ activity. PFOA, PFOS, and 6:2 FTOH also activated Nrf2 in ToxCast assays (Table 5). 
Table 4. ToxCast assays targeting extracellular matrix remodeling, coagulation, and fibrinolysis.

\begin{tabular}{|c|c|c|c|c|c|c|}
\hline Gene Name and Function & ToxCast Assay Name & TBHQ & FD\&C Red 3 & PFOS & PFDA & PFUnDA \\
\hline $\begin{array}{c}\text { Coagulation factor III } \\
\text { Involved in the innate immune response and host } \\
\text { defense against infection, } \\
\text { initiates the coagulation cascades }\end{array}$ & BSK_LPS_TissueFactor_down & $\checkmark$ & & & & \\
\hline \multirow{2}{*}{$\begin{array}{l}\text { Matrix metallopeptidase } 1 \\
\text { Enzyme that breaks down extracellular matrix; } \\
\text { involved in the immune response to infection }\end{array}$} & BSK_BE3C_MMP1_down & & $\checkmark$ & & & \\
\hline & BSK_hDFCGF_MMP1_down & $\checkmark$ & $\checkmark$ & & & $\checkmark$ \\
\hline $\begin{array}{l}\text { Matrix metallopeptidase } 9 \\
\text { Enzyme that breaks down extracellular matrix; } \\
\text { involved in the immune response to infection }\end{array}$ & BSK_KF3CT_MMP9_down & & $\checkmark$ & $\checkmark$ & $\checkmark$ & $\checkmark$ \\
\hline $\begin{array}{l}\text { Tissue plasminogen activator } \\
\text { Secreted serine protease that converts the } \\
\text { plasminogen to plasmin, } \\
\text { regulates innate immune response }\end{array}$ & BSK_BE3C_tPA_down & & $\checkmark$ & & $\checkmark$ & $\checkmark$ \\
\hline \multirow{2}{*}{$\begin{array}{c}\text { Urokinase-type plasminogen activator } \\
\text { Secreted serine protease that converts the } \\
\text { plasminogen to plasmin, } \\
\text { regulates innate immune response }\end{array}$} & BSK_BE3C_uPA_down & & $\checkmark$ & & & $\checkmark$ \\
\hline & BSK_KF3CT_uPA_down & & $\checkmark$ & & & $\checkmark$ \\
\hline Urokinase-type plasminogen activator receptor & BSK_3C_uPAR_down & & $\checkmark$ & & & \\
\hline \multirow{3}{*}{$\begin{array}{l}\text { SERPINE1 (serpin peptidase inhibitor, clade E) } \\
\text { Involved in the innate immune response and early } \\
\text { host defense against infection, } \\
\text { an inhibitor of fibrinolysis }\end{array}$} & & & & & & \\
\hline & BSK_BE3C_PAI1_down & & $\checkmark$ & & $\checkmark$ & $\checkmark$ \\
\hline & BSK_hDFCGF_PAI1_down & $\checkmark$ & $\checkmark$ & & & $\checkmark$ \\
\hline \multirow{2}{*}{$\begin{array}{c}\text { Thrombomodulin } \\
\text { Transmembrane receptor, } \\
\text { suppresses coagulation and inflammation }\end{array}$} & BSK_CASM3C_Thrombomodulin_down & & $\checkmark$ & & & \\
\hline & BSK_CASM3C_Thrombomodulin_up & $\checkmark$ & & & & \\
\hline $\begin{array}{l}\text { TIMP metallopeptidase inhibitor } 1 \\
\text { Inhibitor of the enzymes that break down } \\
\text { extracellular matrix; } \\
\text { regulates innate immune response }\end{array}$ & BSK_hDFCGF_TIMP1_down & $\checkmark$ & $\checkmark$ & & & $\checkmark$ \\
\hline $\begin{array}{l}\text { TIMP metallopeptidase inhibitor } 2 \\
\text { Inhibitor of the enzymes that break down } \\
\text { extracellular matrix; } \\
\text { regulates innate immune response }\end{array}$ & BSK_KF3CT_TIMP2_down & & $\checkmark$ & & & $\checkmark$ \\
\hline
\end{tabular}


Table 5. Transcription factors affected by tert-butylhydroquinone and other compounds in ToxCast assays.

\begin{tabular}{|c|c|c|c|c|c|c|c|}
\hline Gene Name and Function & ToxCast Assay Name & TBHQ & FD\&C Red 3 & 6:2 FTOH & PFOS & PFOA & PFUnDA \\
\hline $\begin{array}{l}\text { Aryl hydrocarbon receptor (AhR) } \\
\text { Involved in xenobiotic response }\end{array}$ & $\begin{array}{c}\text { ATG_Ahr_CIS_up } \\
\text { OX21_AhR_LUC_Agonist* }\end{array}$ & 2 & & & & & \\
\hline \multirow{2}{*}{$\begin{array}{c}\text { Nuclear factor, erythroid 2-like } 2 \\
\text { (NFE2L2, Nrf2) } \\
\text { Involved in oxidative stress, } \\
\text { inflammation, and injury }\end{array}$} & ATG_NRF2_ARE_CIS_up & $\checkmark$ & & $\checkmark$ & $\checkmark$ & $\checkmark$ & \\
\hline & TOX21_ARE_BLA_agonist_ratio & $\checkmark$ & & & & $\checkmark$ & \\
\hline $\begin{array}{l}\text { Glucocorticoid receptor (nuclear } \\
\text { receptor subfamily 3, group C, } \\
\text { member 1) } \\
\text { Involved in regulation of stress } \\
\text { response, inflammation, and immune } \\
\text { processes }\end{array}$ & TOX21_GR_BLA_Antagonist_ratio & $\checkmark$ & & & $\checkmark$ & & $\checkmark$ \\
\hline
\end{tabular}

Note: * This assay had an $\mathrm{AC}_{50}$ value greater than the calculated cytotoxicity limit for TBHQ.

Overall, we were surprised that PFAS with chain length shorter than 10 fluorinated carbons showed limited or no effect in immune-related assays in ToxCast because peerreviewed scientific literature and authoritative agency assessments reported that multiple members of the PFAS class, including PFNA, PFOS, and PFOA as well as PFAS mixtures, show toxicity to the immune system both in laboratory animal studies and in human epidemiological studies [35,47].

\subsection{Correlation Analysis of ToxCast and Immunological Data for TBHQ}

In our analysis, TBHQ emerged as an example of a chemical with strong data availability both in high-throughput assays and in immunological studies. Based on PubMed searches, we identified specific molecular targets reported for TBHQ in studies published over the past decade (Appendix A Table A2) and compared them to ToxCast data.

Immunological studies documented TBHQ's influence on immune functions and parameters including altered T-cell, B-cell, and NK cell function. TBHQ's effects reported in multiple studies include increased Nrf2 expression and transcriptional activity, a decrease in NFKB transcriptional activity, lower expression of the cell surface receptors CD69 and CD25, and inhibition of IL-2 and IFN- $\gamma$ secretion $[45,46,53,57,58]$, as summarized in Table 6 . Additionally, Koh et al. [59] reported that TBHQ attenuated the increase in the production of pro-inflammatory mediators TNF $\alpha, \mathrm{IL}-1 \beta, \mathrm{IL}-6$, and prostaglandin E2. While most of the molecular targets of TBHQ reported in prior studies did not have corresponding ToxCast assays, six targets had such assays (Table 6).

Table 6. Cellular and molecular targets affected by TBHQ that have ToxCast assays.

\begin{tabular}{ccc}
\hline $\begin{array}{c}\text { TBHQ Target Reported in } \\
\text { Immunological Studies }\end{array}$ & Studies Reporting This Target & ToxCast Assay Direction \\
\hline Increased activity of Nrf2 & {$[45,46,53]$} & up \\
Decreased activity of NFKB & {$[46,58]$} & down * \\
Decreased CD69 expression & {$[45,57]$} & down \\
CCL2 increase & {$[53]$} & down \\
TNF $\alpha$ decrease & {$[59]$} & down \\
IL-6 decrease & {$[59]$} & no activity \\
\hline
\end{tabular}

Note: * Active assay with several data quality flags identified in ToxCast.

Modeled $\mathrm{AC}_{50}$ concentrations for TBHQ activity in immune-specific assays in ToxCast, as reported in the CompTox Dashboard, were in the micromolar range, varying between 1.38 and $10.90 \mu \mathrm{M}$. Immunological studies of TBHQ reported activity in a similar dose range of 0.1-300 $\mu \mathrm{M}$ (Appendix A Table A2). In our view, the concordance between TBHQ targets observed in ToxCast and in immunological studies (Table 6) increases the confidence in the potential of ToxCast to identify at least some immunotoxicity effects that would be relevant to human risk assessment. Studies are needed to analyze how the effects reported 
in high-throughput screening assays may translate to changes in specific immune functions such as defense against pathogens, autoimmunity, and anti-tumor immunity.

\section{Discussion}

In 2020, the COVID-19 pandemic stimulated public and scientific attention to the environmental factors that can impact the immune system [60]. As a step towards this important goal, our study investigated the use of high-throughput ToxCast data for assessing immunotoxicity. We focused on chemicals added to food, a group well represented in ToxCast $[32,33,61]$. In addition to direct food additives, our study also included PFAS, substances that are not considered food additives, yet end up in food due to migration out of food contact materials [37,38,41]. Most food additives in the U.S. were approved decades ago and stayed on the market without a requirement for the manufacturers to conduct new toxicity studies [62]. While the U.S. FDA guidance for the safety review of food ingredients mentions immunotoxicity assessment [63], such testing is not required for previously approved additives. For food contact substances, U.S. FDA guidance mentions immunotoxicity studies only for substances with high daily exposure [64]. Recent publications noted that the total extent of exposure to food contact substances and their health and environmental effects remain unknown [65] and called for additional research on developmental immunotoxicity assessment of food contact materials [66].

Analyzing the ToxCast datasets for assay targets relevant to the immune system, we identified several distinct situations: (1) where in vitro screening does not show results expected from in vivo studies; (2) where in vitro screening data agree with immunological studies; and (3) where in vitro screening data point to a risk to the immune system that has not been previously reported and should be further investigated (Table 7).

Table 7. Summary of findings comparing high-throughput data with other data types.

\begin{tabular}{|c|c|c|c|c|}
\hline Chemical & ToxCast & Laboratory Animal Studies & Epidemiological Studies & Conclusion \\
\hline FD\&C Red 3 & $\begin{array}{c}\text { Affects multiple } \\
\text { immune parameters }\end{array}$ & No studies identified & No studies identified & $\begin{array}{c}\text { Potential for } \\
\text { immunotoxic effects, } \\
\text { should be further } \\
\text { investigated }\end{array}$ \\
\hline TBHQ & $\begin{array}{c}\text { Affects multiple } \\
\text { immune parameters }\end{array}$ & $\begin{array}{l}\text { Immune modulation, } \\
\text { changes in the immune } \\
\text { functions }\end{array}$ & No studies identified & $\begin{array}{l}\text { Immunological and } \\
\text { mechanistic studies } \\
\text { point to risk for the } \\
\text { immune system }\end{array}$ \\
\hline PFUnDA & $\begin{array}{l}\text { Affects multiple } \\
\text { immune parameters }\end{array}$ & $\begin{array}{l}\text { Some evidence of immune } \\
\text { suppression }\end{array}$ & Immune suppression & $\begin{array}{l}\text { Human data and } \\
\text { mechanistic studies } \\
\text { point to risk for the } \\
\text { immune system }\end{array}$ \\
\hline PFOA & $\begin{array}{l}\text { Does not show strong } \\
\text { activity in ToxCast } \\
\text { assays with } \\
\text { immune targets }\end{array}$ & Immune suppression & Immune suppression & $\begin{array}{l}\text { Human data point to } \\
\text { risk for the immune } \\
\text { system with limited } \\
\text { support from } \\
\text { mechanistic studies }\end{array}$ \\
\hline
\end{tabular}

For TBHQ and perfluoroundecanoic acid, ToxCast data indicate activation of multiple immune-related end points, in agreement with the available evidence from laboratory animal or epidemiological studies. In contrast, food colorant FD\&C Red 3 has ToxCast data suggestive of immunotoxicity but lacks animal and epidemiological evidence, while PFOA does not show strong activity in ToxCast assays with immune targets yet has strong evidence of immunotoxicity in toxicological and epidemiological studies. Examples where high-throughput data are not in alignment with "classical" toxicological, epidemiological or immunological studies suggest that the current ToxCast datasets are not sufficient to confirm the lack of immunotoxicity. 
The data for FD\&C Red 3 were particularly intriguing. Recently, Chappell et al. reported that this compound shows activity in several ToxCast assays relevant to neurodevelopmental processes [67]. In PubMed searches, we could not identify a study testing the immune system effects of this colorant. Strong activity of FD\&C Red 3 on immune-related targets in ToxCast suggests to us that this endpoint should be analyzed further.

Based on the data showing TBHQ immune activity in animal and mechanistic studies, it is important to assess how TBHQ may affect the immune system in people. Despite the differences in murine and human immune systems, including immune cell population ratios and the presence or absence of certain chemokines, the majority of immune cell transcriptomes are conserved between mice and humans [68,69]. For TBHQ, we noted a concordance between immune targets identified in assays on mice or in murine cells (Appendix A Table A2) and ToxCast targets in primary human cells used for the BioSeek assays (Table 6). More studies are needed to elucidate potential effects of TBHQ on immune parameters such as defense against infection, anti-tumor immune responses, and autoimmune reactivity. One recent study reported that intraperitoneal injection of TBHQ recruited innate immune cells and rendered mice less susceptible to mouse cytomegalovirus infection [53]. In contrast, another study reported that dietary exposure to TBHQ impaired NK cell cytotoxicity against influenza infection [44]. These distinct results may be related to the route of TBHQ exposure, the route of viral infection, or the skewing effects of TBHQ on the differentiation of $T_{h} 1$ and $T_{h} 2$ helper $T$ cells [70]. The change in the $T_{h} 1-T_{h} 2$ cell balance represents an immunomodulatory effect that can affect distinct immunologic endpoints such as response against different types of pathogens, allergic response, and autoimmune conditions, all of which are complex, orchestrated outcomes that cross the definitions of immunosuppression and immunoenhancement.

Given the immunological activity of TBHQ, it is puzzling why this endpoint was previously overlooked. TBHQ was reviewed by the Joint FAO-WHO Expert Committee Report on Food Additives [71], the U.S. National Toxicology Program (NTP) [72], and the European Food Safety Authority [73], and none of these authoritative agencies highlighted the potential for TBHQ to harm the immune system. Reviewing the original studies cited in published assessments, we noted that TBHQ's effects on the immune system were cited in those documents but did not receive further review or investigation. The NTP observed changes in the spleen of laboratory rodents exposed to TBHQ in the diet, such as the elevated incidence of splenic pigmentation known as hemosiderin. The NTP report described the effects on the spleen in the following way: "The pathogenesis of this change remains uncertain, and the biological significance was considered minimal" [72].

We also identified a two-week in vivo immunotoxicity study conducted in 1987 under contract with the NTP; while that study was not published in peer-reviewed literature, it was cited in the European Food Safety Authority report on TBHQ [73]. That study reported that TBHQ exposure increased spleen weight, decreased neutrophil counts, increased NK cell activity, increased serum complement $\mathrm{C} 3$ and increased Fc-mediated adherence and phagocytosis by peritoneal adherent cells. The study described these immune system changes as a "physiologic response" to TBHQ (cited in [73]). Such statements from earlier assessments illustrate how the risk of chemical toxicity to the immune system was disregarded.

The toxicity of PFAS to the immune system was demonstrated in epidemiological studies and toxicological experiments in laboratory animals [47]. The presence of PFAS in people, extensively documented through biomonitoring studies, correlates with attenuated antibody response to vaccinations in children and adults [35]. Some studies reported a correlation between PFAS levels in the body and lower resistance to disease or an increased risk of infections [74,75]. A relationship between higher PFAS levels and increased risk of asthma was reported [76] as well as an association between higher PFAS levels and increases in adolescent food allergies [77]. In 2020, the European Food Safety Authority identified the immunotoxicity of PFAS as the critical health effect [35]. 
In light of the epidemiological findings, the lack of immune-related effects in ToxCast for PFOA and other PFAS opens important questions for future research. The discrepancy between the behavior of certain PFAS in ToxCast and their effects in vivo may be related to the nature of PFAS interactions with cells and cellular processes. The exact mechanism of PFAS toxicity remains under research, although available data suggest the involvement of PPAR $\alpha$, NFKB and Nrf2 [78-82]. Previous studies reported PFAS effects on ToxCast assays targeting estrogen receptor, peroxisome proliferator-activated receptors (PPAR) alpha and gamma, pregnane $X$ receptor, and androgen receptor [26]. The investigation of PPAR $\alpha$ independent mechanisms of PFAS toxicity also suggests suppression of STAT5B [49], a transcription factor activated by cytokines and involved in the immune cell development and autoimmunity [83]. Further, there is a growing body of research on the cross-talk between the endocrine and the immune systems [84], and some impacts of PFAS may be endocrine-mediated. Finally, ToxCast data summarized in Table 5 indicate that $6: 2 \mathrm{FTOH}$, PFOA, and PFOS were active in assays targeting the transcription factor Nrf2. Recent studies have identified Nrf2 as a mediator of PFAS toxicity and signaling in mouse testis and liver as well as frog liver [79-81]. However, PFOA's effect on Nrf2-mediated pathways seems to be distinct from other established Nrf2 activators [82].

Structurally, PFAS examined here are similar to fatty acids with carbon-fluorine bonds instead of carbon-hydrogen bonds. Due to their physicochemical nature, PFAS repel both water and lipids. PFAS bind to protein targets, such as serum albumin [85], peroxisome proliferator-activated receptor [86], and estrogen receptor [87]. PFAS also interact with, insert into, and disrupt phospholipid bilayer and model membranes $[88,89]$. Hypothetically, the membrane-disrupting effects of PFAS may translate into an impact on the physiological processes that depend on transmembrane receptors such as immune recognition and immune defense against pathogens. Future mechanistic studies of PFAS interaction with lymphocytes and other cell types may be able to address this hypothesis and shed light on the molecular mechanisms of PFAS immunotoxicity.

The PFAS example shows the limitations of the currently available high-throughput assays for immunotoxicity screening. The existing assays likely do not capture the full extent of the possible mechanisms of immunotoxicity, especially since different subpopulations of immune cells play distinct roles in the immune defense against different infectious agents and anti-tumor immunity [90]. The lack of ToxCast activity does not indicate that a substance does not impact a particular biological system, such as the immune system, because assays for a specific outcome or a toxicological endpoint might not be in ToxCast as yet. In contrast, the TBHQ analysis supports the value of such approaches, since a strong correlation is seen between high-throughput screening data for TBHQ and findings from immunological assays. Future immunotoxicity studies of FD\&C Red 3 may provide further information for probing this relationship between different types of data and verifying the ToxCast results for this substance.

\section{Conclusions}

Joint consideration of toxicological and high-throughput screening data suggests that chemicals directly or indirectly added to food for decades - such as PFAS and TBHQmay show previously unanticipated effects on the immune system. From the public policy perspective, the discovery of impacts on human health of substances that have long been used in consumer products and food products suggests that the pre-market safety evaluation of these substances was inadequate. We recommend that immunotoxicity testing should be prioritized in order to protect public health, and immunotoxicity analysis should be, in our estimate, an integral part of chemical safety assessment.

Author Contributions: Conceptualization, O.V.N.; methodology, O.V.N. and S.P.-G.; software, S.P.-G.; validation, A.M.T. and D.Q.A.; formal analysis, A.M.T., D.Q.A. and O.V.N.; data curation, S.E., T.S. and U.I.U.; writing—original draft preparation, O.V.N.; writing—review and editing, A.M.T., D.Q.A., O.V.N., S.E., T.S. and U.I.U.; visualization, S.E. All authors have read and agreed to the published version of the manuscript. 
Funding: Partial support for this work was provided by a grant from the Leon Lowenstein Foundation (United States).

Institutional Review Board Statement: This research project did not involve humans or animals.

Data Availability Statement: This analysis is based on open access datasets from the U.S. EPA ToxCast (https: / / comptox.epa.gov / dashboard, accessed on 24 September 2020), and the Comparative Toxicogenomics Database (http:/ / ctdbase.org, accessed on 24 September 2020).

Acknowledgments: The authors thank former intern Rundong Ji for assistance with the figure design.

Conflicts of Interest: The authors declare no conflict of interest.

\section{Appendix A}

Table A1. Studies of PFAS migration from food contact materials.

\begin{tabular}{|c|c|c|c|}
\hline Material Tested & Migration Conditions & Detections of PFAS $^{1}$ & Findings \\
\hline $\begin{array}{l}\text { Cookware and food } \\
\text { packaging } \\
\text { United States, } 2005 \text { [91] }\end{array}$ & $\begin{array}{l}\text { PFOA leaching into Miglyol } \\
\text { and water was measured from } \\
\text { different products, including } \\
\text { popcorn bag, hamburger } \\
\text { wrapper, sandwich wrapper, } \\
\text { French fry box, and paper } \\
\text { plates. }\end{array}$ & PFOA & $\begin{array}{l}\text { Paper coatings with } \\
\text { fluorotelomers released } \\
\text { significantly higher amounts } \\
\text { of PFOA than other tested } \\
\text { products. The highest } \\
\text { concentration of PFOA was } \\
\text { released from microwave } \\
\text { popcorn bags. }\end{array}$ \\
\hline $\begin{array}{l}\text { Fast food wrappers } \\
\text { United States, } 2008 \text { [92] }\end{array}$ & $\begin{array}{l}\text { PFAS migration measured } \\
\text { from three retail fast food } \\
\text { wrappers into food and food } \\
\text { simulants (Miglyol, butter, } \\
\text { water, vinegar, chocolate } \\
\text { spread, and water / ethanol } \\
\text { solutions (10, 20, 25, and } 30 \% \\
\text { ethanol). Migration tests were } \\
\text { run with } 100{ }^{\circ} \mathrm{C} \text { food/food } \\
\text { simulant added to paper for } \\
15 \text { min; butter was tested at } 4 \\
{ }^{\circ} \mathrm{C} \text { for } 40 \text { days. }\end{array}$ & 3 PFAS species tested ${ }^{2}$ & $\begin{array}{l}\text { Reported significantly higher } \\
\text { migration of PFAS into butter } \\
\text { and other oil emulsion } \\
\text { mixtures compared with } \\
\text { migration into water, vinegar, } \\
\text { oils, or alcohol. }\end{array}$ \\
\hline $\begin{array}{c}\text { Frying pans } \\
\text { United States, } 2007 \text { [93] }\end{array}$ & $\begin{array}{l}\text { Pans were heated for } 30 \text { min at } \\
250{ }^{\circ} \mathrm{C} \text { and the headspace gas } \\
\text { was tested for a characteristic } \\
\text { perfluorinated substance } \\
\text { fragment, "-CF2-CF3". }\end{array}$ & None reported & $\begin{array}{l}\text { Did not detect PFAS } \\
\text { compounds in the } \\
\text { headspace gas. }\end{array}$ \\
\hline $\begin{array}{c}\text { Frying pans, cooking utensils, } \\
\text { grill pans, pots, rice cookers, } \\
\text { and non-stick baking papers. } \\
\text { Korea, } 2018 \text { [94] }\end{array}$ & $\begin{array}{l}\text { Analysis of PFAS migration } \\
\text { from } 312 \text { food contact } \\
\text { materials into food simulants, } \\
\text { water, and corn oil at varying } \\
\text { conditions: } 4 \% \text { acetic acid at } \\
100{ }^{\circ} \mathrm{C} \text { for } 30 \mathrm{~min} ; 50 \% \\
\text { ethanol and } 50 \% \text {-heptane at } \\
70{ }^{\circ} \mathrm{C} \text { for } 30 \text { min followed by } \\
\text { incubation at } 25^{\circ} \mathrm{C} \text { for } 1 \mathrm{~h} \text {. }\end{array}$ & $\begin{array}{c}\text { PFOA, PFNA, PFDoDA, } \\
\text { PFTrDA, PFTeDA, PFHxDA, } \\
\text { PFODA }\end{array}$ & $\begin{array}{l}\text { Seven PFAS migrated into } \\
\text { food simulants from } 10 \text { frying } \\
\text { pans and } 2 \text { baking utensils. } \\
\text { No PFAS migration was } \\
\text { observed during subsequent } \\
\text { testing and PFAS did not } \\
\text { migrate from frying pans into } \\
\text { corn oil or water. }\end{array}$ \\
\hline
\end{tabular}


Table A1. Cont.

\begin{tabular}{|c|c|c|c|}
\hline Material Tested & Migration Conditions & Detections of PFAS ${ }^{1}$ & Findings \\
\hline $\begin{array}{l}\text { Pet food paper bag }{ }^{3} \\
\text { Spain, } 2019 \text { [95] }\end{array}$ & $\begin{array}{l}\text { Analysis of PFAS migration } \\
\text { from paper bag packaging } \\
\text { into food simulant (Tenax) } \\
\text { and milk at various } \\
\text { conditions: } 10 \text { days at } 40^{\circ} \mathrm{C} ; 2 \\
\text { h at } 80^{\circ} \mathrm{C}, 120^{\circ} \mathrm{C} \text { and } 160^{\circ} \mathrm{C}\end{array}$ & $\begin{array}{c}\text { PFBA, PFPeA, PFHxA, } \\
\text { PFHpA, PFOA, PFNA, PFDA, } \\
\text { PFUnDA, PFDoDA, PFTrDA, } \\
\text { PFTeDA }\end{array}$ & $\begin{array}{l}\text { Greater migration was } \\
\text { observed into milk than the } \\
\text { food simulant, and high } \\
\text { migration percentages were } \\
\text { observed for long-chain PFAS. } \\
\text { Migration rates increased } \\
\text { with temperature. }\end{array}$ \\
\hline 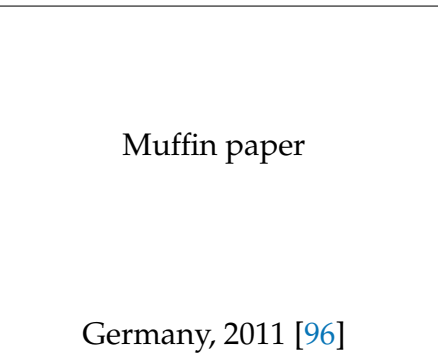 & $\begin{array}{l}\text { Migration of fluorotelomers } \\
\text { from muffin containers into } \\
\text { butter, muffin dough, and } \\
\text { Tenax food simulant } \\
\text { measured after exposure to } \\
\text { oven temperatures of } 120-200 \\
{ }^{\circ} \mathrm{C} \text { for } 5 \text { to } 60 \mathrm{~min} \text {. }\end{array}$ & $\begin{array}{c}8: 2 \mathrm{FTOH} \\
10: 2 \mathrm{FTOH}\end{array}$ & $\begin{array}{l}\text { The fluorotelomer } \\
\text { concentrations were higher in } \\
\text { the dough, butter, and Tanex } \\
\text { food simulant after heating } \\
\text { compared to the original } \\
\text { levels in the baking cup paper, } \\
\text { indicating the release of } \\
\text { fluorotelomers from } \\
\text { precursor compounds. }\end{array}$ \\
\hline $\begin{array}{l}\text { Microwave popcorn and } \\
\text { foods in paper packaging } \\
\text { Sweden, } 2013 \text { [97] }\end{array}$ & $\begin{array}{l}\text { PFAS were tested in food } \\
\text { samples before and after } \\
\text { preparation as directed on the } \\
\text { packaging. }\end{array}$ & $\begin{array}{c}\text { 6:2 diPAP, 8:2 diPAP, 10:2 } \\
\text { diPAP, PFHxA, PFOA, PFNA, } \\
\text { PFDA, PFUnDA, PFTrDA }\end{array}$ & $\begin{array}{l}\text { The PFAS concentrations, } \\
\text { notably for polyfluoroalkyl } \\
\text { phosphoric acid diesters } \\
\text { (diPAP), increased in some } \\
\text { packaged foods tested after } \\
\text { heating in accordance with the } \\
\text { package directions. }\end{array}$ \\
\hline $\begin{array}{l}\text { Instant food cups, } \\
\text { microwave-popcorn bags, } \\
\text { beverage cups, ice cream cups, } \\
\text { fast food containers, dessert } \\
\text { containers, and baking papers } \\
\text { Thailand, } 2012 \text { [ } 98 \text { ] }\end{array}$ & $\begin{array}{l}\text { The leaching of PFOA and } \\
\text { PFOS from } 34 \text { food packaging } \\
\text { products into methanol and } \\
\text { saliva simulant at } 80^{\circ} \mathrm{C} \\
\text { during a } 30 \text { min period. }\end{array}$ & PFOA, PFOS & $\begin{array}{l}\text { PFOA and PFOS migrated } \\
\text { into saliva simulant from the } \\
\text { majority of samples, all of } \\
\text { which had detectable PFOA or } \\
\text { PFOS. The highest migration } \\
\text { of PFOA and PFOS was } \\
\text { reported for a French-fry box } \\
\text { and hot beverage cup. }\end{array}$ \\
\hline
\end{tabular}

Frying pans $\quad 11$ frying pans into water, $10 \%$

United States, 2005 [99] $\quad \begin{aligned} & \text { measured after heating to } 125 \\ & \text { manol, }\end{aligned}$

${ }^{\circ} \mathrm{C}$.
None reported

No PFOA was detected in any samples.
Frying pans, sandwich maker, waffle irons

Germany, 2015 [100]
Volatilization of 9 PFAS into air was measured under normal use and under overheating scenarios.
PFBA, PFPeA, PFHxA, PFHpA, PFOA, PFNA, PFDA, PFUnDA, PFDoDA
PFAS release increased significantly at overheating temperatures, and all 9 PFAS

were detected. PFOA emissions were lower than in prior reports.
The migration of 10 PFAS into air and water was measured from pans heated on a hotplate set to $250{ }^{\circ} \mathrm{C}$ and from microwave popcorn after microwave heating for $3 \mathrm{~min}$.
PFPeA, PFHpA, PFOA, PFNA, PFDA, PFUnDA, PFDoDA, 6:2 FTOH, 8:2 FTOH
PFOA was released into the air from frying pans at normal cooking temperatures during consequent uses. One brand

of microwave popcorn released much higher levels of PFAS compared to the other two. 
Table A1. Cont.

\begin{tabular}{|c|c|c|c|}
\hline Material Tested & Migration Conditions & Detections of PFAS ${ }^{1}$ & Findings \\
\hline $\begin{array}{l}\text { Butter wrappers and dairy } \\
\text { processing equipment } \\
\text { Germany, 2013 [102] }\end{array}$ & $\begin{array}{l}\text { Concentrations of } 9 \text { PFAS } \\
\text { were measured in dairy } \\
\text { products during processing. } \\
\text { Migration of PFAS from butter } \\
\text { wrappers was measured after } \\
45 \text { days at } 5^{\circ} \mathrm{C} \text {. }\end{array}$ & $\begin{array}{l}\text { PFBA, PFPeA. PFHxA, } \\
\text { PFHpA, PFOA, PFNA, PFDA, } \\
\text { PFDoA, 8:2 FTOH, 10:2 FTOH }\end{array}$ & $\begin{array}{l}\text { Greater migration of PFOA } \\
\text { and PFHxA relative to the } \\
\text { longer-chain PFAS was } \\
\text { observed from the butter } \\
\text { wrapper. PFAS concentrations } \\
\text { increased with greater fat } \\
\text { concentrations in dairy } \\
\text { products. }\end{array}$ \\
\hline $\begin{array}{l}\text { Two paper food contact } \\
\text { materials } \\
\text { United States, } 2013 \text { [103] }\end{array}$ & $\begin{array}{c}\text { Migration of PFAS from two } \\
\text { paper food packaging into } \\
\text { five simulants (Miglyol oil, } \\
\text { Miglyol oil with soy lecithin, } \\
\text { Miglyol oil with Tween 60, } \\
10 \% \text { ethanol, } 3 \% \text { acetic acid) } \\
\text { under two temperatures: } 100 \\
{ }^{\circ} \mathrm{C}\left(15 \text { min) and } 40{ }^{\circ} \mathrm{C}(2,24,\right. \\
96 \text { and } 240 \mathrm{~h}) .\end{array}$ & $\begin{array}{l}\text { PFHxA, PFHpA, PFOA, } \\
\text { PFNA, PFDA, PFUnDA, } \\
\text { PFDoDA }\end{array}$ & $\begin{array}{l}\text { Seven PFAS migrated into } \\
\text { food stimulants, and the } \\
\text { shorter chain compounds } \\
\text { migrated at a faster rate. The } \\
\text { addition of emulsifiers } \\
\text { increased migration } \\
\text { efficiencies. Paper coating } \\
\text { based on di-perfluoro- } \\
\text { alkyloxy-amino-acid leached } \\
\text { PFAS at a higher rate } \\
\text { compared to the coating based } \\
\text { on polyfluoroalkyl phosphate } \\
\text { surfactants. }\end{array}$ \\
\hline $\begin{array}{c}\text { Paper bowl } \\
\text { China, } 2016 \text { [104] }\end{array}$ & $\begin{array}{l}\text { Migration studies of } 16 \text { PFAS } \\
\text { from paper bowls into several } \\
\text { food simulants: oil, water, and } \\
\text { ethanol/water mixtures } \\
(10 / 90,30 / 70,50 / 50) . \\
\text { Simulants preheated to } 100{ }^{\circ} \mathrm{C} \\
\text { were added to a bowl, } \\
\text { followed by a } 15 \text {-min hold at } \\
\text { room temperature. }\end{array}$ & $\begin{array}{c}\text { 6:2 FTOH, 8:2 FTOH, 10:2 } \\
\text { FTOH, 12:2 FTOH, 14:2 FTOH; } \\
\text { 16:2 FTOH, PFBA, PFPeA, } \\
\text { PFHxA, PFHpA, PFOA, } \\
\text { PFNA, PFDA, PFUnDA, } \\
\text { PFDoDA, PFTrDA, PFTeDA, } \\
\text { PFPeDA, PFHxDA, PFHpDA, } \\
\text { PFODA }\end{array}$ & $\begin{array}{l}\text { Perfluorinated carboxylic } \\
\text { acids and fluorotelomer } \\
\text { alcohols readily migrated out } \\
\text { of the paper bowls, with a } \\
\text { greater transfer into } 50 \% \\
\text { ethanol relative to } 30 \% \\
\text { ethanol or water. PFBA } \\
\text { (compound with } 4 \text { fluorinated } \\
\text { carbons) had the greatest } \\
\text { migration efficiency. }\end{array}$ \\
\hline $\begin{array}{l}\text { Pet food paper bag }{ }^{3} \\
\text { Spain, } 2020 \text { [105] }\end{array}$ & $\begin{array}{l}\text { Migration of } 12 \text { PFAS from } \\
\text { unprinted pet food paper bags } \\
\text { was measured to food } \\
\text { simulants (Tenax, } 50 \% \text { ethanol, } \\
\text { and } 95 \% \text { ethanol) and foods } \\
\text { (ground cereal, parboiled rice, } \\
\text { infant milk powder). }\end{array}$ & $\begin{array}{l}\text { PFPeA, PFHxA, PFHpA, } \\
\text { PFOA, PFNA, PFDA, 8:2 } \\
\text { FTCA, 8:2 FTUCA }\end{array}$ & $\begin{array}{l}\text { Shorter chain PFAS exhibited } \\
\text { greater migration efficiencies } \\
\text { than long-chain PFAS. More } \\
\text { migration was observed into } \\
\text { milk powder compared to } \\
\text { food simulants. }\end{array}$ \\
\hline
\end{tabular}

Note: ${ }^{1}$. diPAPs: Polyfluoroalkyl phosphoric acid diesters; PFBA: Perfluorobutanoate; PFPeA: Perfluoropentanoic acid; PFHxA: perfluorohexanoic acid; PFHpA: perfluoroheptanoic acid; PFOA: perfluorooctanoic acid; PFOS: perfluorooctanesulfonic acid; PFNA: perfluorononanoic acid; PFDA: perfluorodecanoic acid; PFUnDA: Perfluoroundecanoic acid; PFDoDA: perfluorododecanoic acid; PFTrDA: Perfluorotridecanoate; PFTeDA: Perfluorotetradecanoate; PFPeDA Perfluoropentadecanoate; PFHxDA: Perfluorohexadecanoate; PFHpDA: Perfluoroheptadecanoate; PFODA: Perfluorooctadecanoate; 8:2 FTCA: 2-perfluorooctyl ethanoic acid; 8:2 FTUCA: 2H-perfluoro-2-decenoic acid; 8:2 FTOH: 8:2 fluorotelomer alcohol; 10:2 FTOH: 10:2 fluorotelomer alcohol; 6:2 DiPAP: 6:2 Fluorotelomer phosphate diester; 8:2 DiPAP: 8:2 Fluorotelomer phosphate diester; 10:2 DiPAP: 10:2 Fluorotelomer phosphate diester. ${ }^{2}$. PFAS tested by Begley et al. (2008): phosphoric acid, bis[(3,3,4,4,5,5,6,6,7,7,8,8,9,9,10,10,10-heptadeca-fluoro-decyl)]2-(2-hydroxyethyl amino) salt; phosphoric acid, bis $[(3,3,4,4,5,5,6,6,7,7,8,8,9,9,10,10,10$-heptadecafluoro-decylsulfanylmethyl)]-2-hydroxy-2-oxo-1,3,2-dioxaphosphorinane, ammonium salt; phosphoric acid, bis[(N-ethyl-2-1,1,2,2,3,4,4,5,5,6,6,7,7,8,8,8-heptadecafluoro-octylsulfonamidoethyl)])ammonium salt. ${ }^{3}$. Two studies examined PFAS migration from packaging for pet food $[95,105]$, and their findings were similar to the studies of PFAS migration from packaging for food intended for human use. 
Table A2. TBHQ activity reported in immunological studies published between 2011 and 2020.

\begin{tabular}{|c|c|c|}
\hline Study Model & Dose & Main Findings \\
\hline Mouse [44] & $\begin{array}{l}0.0014 \% \text { TBHQ diet fed to mice prior to } \\
\text { infection with influenza virus }\end{array}$ & $\begin{array}{l}\text { NK cell expression of granzyme B was decreased } \\
\text { in the TBHQ-exposed mice, indicating impaired } \\
\text { NK cell cytotoxicity. }\end{array}$ \\
\hline Mouse [106] & $\begin{array}{l}0.001 \% \text { TBHQ diet fed to mice prior to } \\
\text { ovalbumin exposure. }\end{array}$ & $\begin{array}{l}\text { Following ovalbumin sensitization, a higher } \\
\text { concentration of IgE and higher mast cell protease } \\
\text { response were measured in the TBHQ group } \\
\text { compared to controls. }\end{array}$ \\
\hline Mouse [53] & $\begin{array}{c}\text { Single intraperitoneal injection of } 50 \mathrm{mM} \\
\text { TBHQ }\end{array}$ & $\begin{array}{l}\text { TBHQ upregulated cytokine IL-17D in an } \\
\text { Nrf2-dependent manner and chemokine CCL2 in } \\
\text { an Nrf2-independent manner. }\end{array}$ \\
\hline $\begin{array}{l}\text { Murine wild-type and Nrf2-null } \\
\text { splenocytes [45] }\end{array}$ & Cells treated with $0.25-2.5 \mu \mathrm{M}$ TBHQ & $\begin{array}{l}\text { TBHQ enhanced Nrf2-dependent IgM production } \\
\text { in B cells and decreased induction of CD22, CD25, } \\
\text { CD69, and CD138 receptors both in wild-type and } \\
\text { Nrf2-null B cells. }\end{array}$ \\
\hline Murine splenocytes [57] & Cells treated with $1 \mu \mathrm{M}$ or $5 \mu \mathrm{M}$ TBHQ & $\begin{array}{l}\text { Activation of NK cells in the presence of TBHQ } \\
\text { decreased production of IFN-Y, granzyme B, and } \\
\text { perforin, and lowered the induction of CD25 and } \\
\text { CD69. }\end{array}$ \\
\hline $\begin{array}{l}\text { Splenocytes from Nrf2-null and } \\
\text { wild-type mice [46] }\end{array}$ & Cells treated with $0.1-1 \mu \mathrm{M}$ TBHQ & $\begin{array}{c}\text { TBHQ inhibited the production of IL-2 and } \\
\text { Granulocyte-Macrophage Colony-Stimulating } \\
\text { Factor (GM-CSF) in both wild-type and Nrf2-null } \\
\text { T cells. }\end{array}$ \\
\hline Human T cell line [58] & Jurkat cells treated with $0.1-1 \mu \mathrm{M}$ TBHQ & $\begin{array}{c}\text { TBHQ suppression of CD25 expression partly } \\
\text { depended on Nrf2, while TBHQ inhibition of } \\
\text { NFkB activation and IL-2 secretion was } \\
\text { Nrf2-independent. }\end{array}$ \\
\hline Rat thymocytes [107] & Cells treated with $10-300 \mu \mathrm{M}$ TBHQ & $\begin{array}{l}\text { TBHQ exposure activated Ca2+-dependent } \mathrm{K}+ \\
\text { channels and elevated intracellular } \mathrm{Ca} 2+\text { levels. }\end{array}$ \\
\hline $\begin{array}{l}\text { Primary human } \mathrm{CD}^{+} \mathrm{T} \text { cells } \\
{[108]}\end{array}$ & Cells treated with $0.1-5 \mu \mathrm{M}$ TBHQ & $\begin{array}{l}\text { Inactivated human T cells, TBHQ inhibits the } \\
\text { production of IL-2 and IFN- } 8 \text {, inhibits the } \\
\text { induction of CD25 and CD69, and suppresses } \\
\text { NFKB DNA binding. }\end{array}$ \\
\hline Human dendritic cells [109] & Cells treated with $10 \mu \mathrm{M}$ TBHQ & $\begin{array}{l}\text { TBHQ inhibited IL-12 expression in an } \\
\text { Nrf2-dependent manner. }\end{array}$ \\
\hline $\begin{array}{c}\text { Primary human } \mathrm{CD}^{+} \mathrm{T} \text { cells } \\
{[110]}\end{array}$ & Cells treated with $50 \mu \mathrm{M}$ TBHQ & TBHQ increased total Nrf2 levels. \\
\hline Human T cell line [111] & Jurkat cells treated with $0.1-5 \mu \mathrm{M}$ TBHQ & $\begin{array}{l}\text { TBHQ inhibited interleukin-2 and CD25 } \\
\text { expression and decreased NFkB transcriptional } \\
\text { activity. }\end{array}$ \\
\hline Murine T cells [70] & Cells treated with $0.1-1 \mu \mathrm{M}$ TBHQ & $\begin{array}{l}\text { TBHQ suppressed IFN- } \gamma \text { production and induced } \\
\text { IL-4, IL-5, and IL-13 production. }\end{array}$ \\
\hline
\end{tabular}

\section{References}

1. Ferrario, D.; Gribaldo, L.; Hartung, T. Arsenic exposure and immunotoxicity: A review including the possible influence of age and sex. Curr. Environ. Health Rep. 2016, 3, 1-12. [CrossRef] [PubMed]

2. Gilbert, K.M.; Bai, S.; Barnette, D.; Blossom, S.J. Exposure cessation during adulthood did not prevent immunotoxicity caused by developmental exposure to low-level trichloroethylene in drinking water. Toxicol. Sci. 2017, 157, 429-437. [CrossRef] [PubMed]

3. Lee, G.H.; Choi, K.C. Adverse effects of pesticides on the functions of immune system. Comp. Biochem. Physiol. C Toxicol. Pharmacol. 2020, 235, 108789. [CrossRef]

4. Grandjean, P. Delayed discovery, dissemination, and decisions on intervention in environmental health: A case study on immunotoxicity of perfluorinated alkylate substances. Environ Health. 2018, 17, 62. [CrossRef] [PubMed] 
5. Blossom, S.J.; Gilbert, K.M. Epigenetic underpinnings of developmental immunotoxicity and autoimmune disease. Curr. Opin. Toxicol. 2018, 10, 23-30. [CrossRef] [PubMed]

6. Dietert, R.R.; Zelikoff, J.R. Early-life environment, developmental immunotoxicology, and the risk of pediatric allergic disease including asthma. Birth Defects Res. B Dev. Reprod. Toxicol. 2008, 83, 547-560. [CrossRef] [PubMed]

7. Hessel, E.V.; Tonk, E.C.; Bos, P.M.; van Loveren, H.; Piersma, A.H. Developmental immunotoxicity of chemicals in rodents and its possible regulatory impact. Crit. Rev. Toxicol. 2015, 45, 68-82. [CrossRef] [PubMed]

8. Von der Embse, A.N.; De Witt, J.C. Developmental immunotoxicity (DIT) testing: Current recommendations and the future of DIT testing. Methods Mol. Biol. 2018, 1803, 47-56. [CrossRef]

9. Vos, J.G. Immune suppression as related to toxicology. CRC Crit. Rev. Toxicol. 1977, 5, 67-101. [CrossRef] [PubMed]

10. World Health Organization International Programme on Chemical Safety. Guidance for Immunotoxicity Risk Assessment for Chemicals. 2012. Available online: http://www.inchem.org/documents/harmproj/harmproj/harmproj10.pdf (accessed on 15 February 2021).

11. U.S. Congress Office of Technology Assessment. Identifying \& Controlling Immunotoxic Substances Background Paper. 1991. OTA-BP-BA-75. Available online: https:/ / ota.fas.org/reports/9124.pdf (accessed on 15 February 2021).

12. Anderson, S.E.; Shane, H.L. Investigative Immunotoxicology. Methods Mol. Biol. 2018, 1803, 27-46. [CrossRef]

13. Hartung, T.; Corsini, E. Immunotoxicology: Challenges in the 21st century and in vitro opportunities. ALTEX 2013, 30, 411-426. [CrossRef]

14. Hastings, K.L. Immunotoxicology: A brief history. Methods Mol. Biol. 2018, 1803, 3-13. [CrossRef]

15. Burleson, S.C.; Freebern, W.J.; Burleson, F.G.; Burleson, G.R.; Johnson, V.J.; Luebke, R. Host resistance assays. Methods Mol. Biol. 2018, 1803, 117-145. [CrossRef]

16. European Chemical Agency. Guidance on Information Requirements and Chemical Safety Assessment Chapter, R.7a: Endpoint Specific Guidance. 2017. Available online: https://echa.europa.eu/guidance-documents/guidance-on-informationrequirements-and-chemical-safety-assessment (accessed on 15 February 2021).

17. U.S. Environmental Protection Agency. Health Effects Test Guidelines. OPPTS 870.7800. Immunotoxicity. 1998; EPA 712-C-96351. Available online: https://www.epa.gov/test-guidelines-pesticides-and-toxic-substances/series-870-health-effects-testguidelines (accessed on 15 February 2021).

18. U.S. Environmental Protection Agency. Part 158 Toxicology Data Requirements: Guidance for Neurotoxicity Battery, Subchronic Inhalation, Subchronic Dermal and Immunotoxicity Studies. Office of Pesticides Programs. 2013. Available online: https: / /19january2017snapshot.epa.gov/sites/production/files/2014-02/documents/part158-tox-data-requirement.pdf (accessed on 15 February 2021).

19. U.S. Environmental Protection Agency. Design for the Environment Program Alternatives Assessment Criteria for Hazard Evaluation Version 2.0. 2011. Available online: https://www.epa.gov/saferchoice/alternatives-assessment-criteria-hazardevaluation (accessed on 15 February 2021).

20. Rovida, C.; Barton-Maclaren, T.; Benfenati, E.; Caloni, F.; Charukeshi Chandrasekera, P.; Chesné, C.; Cronin, M.T.D.; De Knecht, J.; Dietrich, D.R.; Escher, S.E.; et al. Internationalization of read-across as a validated new approach method (NAM) for regulatory toxicology. ALTEX 2020. [CrossRef]

21. Turley, A.E.; Isaacs, K.K.; Wetmore, B.A.; Karmaus, A.L.; Embry, M.R.; Krishan, M. Incorporating new approach methodologies in toxicity testing and exposure assessment for tiered risk assessment using the RISK21 approach: Case studies on food contact chemicals. Food Chem. Toxicol. 2019, 134, 110819. [CrossRef] [PubMed]

22. Bell, S.; Abedini, J.; Ceger, P.; Chang, X.; Cook, B.; Karmaus, A.L.; Lea, I.; Mansouri, K.; Phillips, J.; McAfee, E.; et al. An integrated chemical environment with tools for chemical safety testing. Toxicol. In Vitro 2020, 67, 104916. [CrossRef] [PubMed]

23. Borrel, A.; Auerbach, S.S.; Houck, K.A.; Kleinstreuer, N.C. Tox21BodyMap: A webtool to map chemical effects on the human body. Nucleic Acids Res. 2020, 48, W472-W476. [CrossRef]

24. Kleinstreuer, N.C.; Yang, J.; Berg, E.L.; Knudsen, T.B.; Richard, A.M.; Martin, M.T.; Reif, D.M.; Judson, R.S.; Polokoff, M.; Dix, D.J.; et al. Phenotypic screening of the ToxCast chemical library to classify toxic and therapeutic mechanisms. Nat. Biotechnol. 2014, 32, 583-591. [CrossRef] [PubMed]

25. Richard, A.M.; Judson, R.S.; Houck, K.A.; Grulke, C.M.; Volarath, P.; Thillainadarajah, I.; Yang, C.; Rathman, J.; Martin, M.T.; Wambaugh, J.F.; et al. ToxCast chemical landscape: Paving the road to 21st century toxicology. Chem. Res. Toxicol. 2016, 29, 1225-1251. [CrossRef] [PubMed]

26. Chiu, W.A.; Guyton, K.Z.; Martin, M.T.; Reif, D.M.; Rusyn, I. Use of high-throughput in vitro toxicity screening data in cancer hazard evaluations by IARC monograph working groups. ALTEX 2018, 35, 51-64. [CrossRef] [PubMed]

27. Iyer, S.; Pham, N.; Marty, M.; Sandy, M.; Solomon, G.; Zeise, L. An integrated approach using publicly available resources for identifying and characterizing chemicals of potential toxicity concern: Proof-of-concept with chemicals that affect cancer pathways. Toxicol. Sci. 2019, 169, 14-24. [CrossRef]

28. Karmaus, P.W.F.; Karmaus, A.L. Challenges for integrating immunotoxicology into the twenty-first-century toxicology testing paradigm. Methods Mol. Biol. 2018, 1803, 385-396. [CrossRef] [PubMed]

29. Davis, A.P.; Grondin, C.J.; Johnson, R.J.; Sciaky, D.; McMorran, R.; Wiegers, J.; Wiegers, T.C.; Mattingly, C.J. The comparative toxicogenomics database: Update 2019. Nucleic Acids Res. 2019, 47, D948-D954. [CrossRef] [PubMed] 
30. Kosnik, M.B.; Planchart, A.; Marvel, S.W.; Reif, D.M.; Mattingly, C.J. Integration of curated and high-throughput screening data to elucidate environmental influences on disease pathways. Comput. Toxicol. 2019, 12, 100094. [CrossRef] [PubMed]

31. Judson, R.; Houck, K.; Martin, M.; Richard, A.M.; Knudsen, T.B.; Shah, I.; Little, S.; Wambaugh, J.; Setzer, R.W.; Kothya, P.; et al. Analysis of the effects of cell stress and cytotoxicity on in vitro assay activity across a diverse chemical and assay space. Toxicol. Sci. 2016, 152, 323-339. [CrossRef]

32. Karmaus, A.L.; Filer, D.L.; Martin, M.T.; Houck, K.A. Evaluation of food-relevant chemicals in the ToxCast high-throughput screening program. Food Chem. Toxicol. 2016, 92, 188-196. [CrossRef] [PubMed]

33. Karmaus, A.L.; Trautman, T.D.; Krishan, M.; Filer, D.L.; Fix, L.A. Curation of food-relevant chemicals in ToxCast. Food Chem. Toxicol. 2017, 103, 174-182. [CrossRef]

34. National Toxicology Program. Report on Carcinogens, Fourteenth Edition. Butylated Hydroxyanisole. Available online: https://ntp.niehs.nih.gov/ntp/roc/content/profiles/butylatedhydroxyanisole.pdf (accessed on 15 February 2021).

35. European Food Safety Authority. Risks to human health related to the presence of perfluoroalkyl substances in food. EFSA J. 2020, 18, e06223. [CrossRef]

36. U.S. Food and Drug Administration. Packaging \& Food Contact Substances (FCS). Available online: https://www.fda.gov/food/ food-ingredients-packaging/packaging-food-contact-substances-fcs (accessed on 15 February 2021).

37. U.S. Food and Drug Administration. Indirect Food Additives: Paper and Paperboard Components. 81 Fed. Reg. 5. Available online: https: / www.federalregister.gov/documents/2016/01/04/2015-33026/indirect-food-additives-paper-and-paperboardcomponents (accessed on 15 February 2021).

38. Rice, P.A. C6-Perfluorinated compounds: The new greaseproofing agents in food packaging. Curr. Environ. Health Rep. 2015, 2, 33-40. [CrossRef]

39. Schaider, L.A.; Balan, S.A.; Blum, A.; Andrews, D.Q.; Strynar, M.J.; Dickinson, M.E.; Lunderberg, D.M.; Lang, J.R.; Peaslee, G.F. Fluorinated compounds in U.S. fast food packaging. Environ. Sci. Technol. Lett. 2017, 4, 105-111. [CrossRef] [PubMed]

40. Susmann, H.P.; Schaider, L.A.; Rodgers, K.M.; Rudel, R.A. Dietary habits related to food packaging and population exposure to PFASs. Environ. Health Perspect. 2019, 127, 107003. [CrossRef] [PubMed]

41. U.S. Food and Drug Administration. FDA Announces the Voluntary Phase-Out by Industry of Certain PFAS Used in Food Packaging. Constituent Update 31 July 2020. Available online: https:/ /www.fda.gov/food/cfsan-constituent-updates/fdaannounces-voluntary-phase-out-industry-certain-pfas-used-food-packaging (accessed on 15 February 2021).

42. Trier, X.; Taxvig, X.; Rosenmai, A.K.; Pedersen, G.A. PFAS in Paper and Board for Food Contact: Options for Risk Management of Poly- and Perfluorinated Substances. Nordisk Ministerråd. 2017. Available online: https://orbit.dtu.dk/files/149769110/ Rapport_PFAS_in_paper_and_board_for_food_contact_Options_for_risk_management_of_poly_and_perfluorina.pdf (accessed on 15 February 2021).

43. Rice, P.A.; Aungst, J.; Cooper, J.; Bandele, O.; Kabadi, S.V. Comparative analysis of the toxicological databases for 6:2 fluorotelomer alcohol (6:2 FTOH) and perfluorohexanoic acid (PFHxA). Food Chem. Toxicol. 2020, 138, 111210. [CrossRef]

44. Boss, A.; Freeborn, R.; Liu, S.; Zagorski, J.; Turley, A.; Gardner, E.; Rockwell, C. The food additive tBHQ impairs NK cell cytotoxicity against influenza infection (FS12-02-19). Curr. Dev. Nutr. 2019, 3, nzz049-FS12. [CrossRef]

45. Bursley, J.K.; Rockwell, C.E. Nrf2-dependent and -independent effects of tBHQ in activated murine B cells. Food Chem. Toxicol. 2020, 145, 111595. [CrossRef]

46. Zagorski, J.W.; Turley, A.E.; Freeborn, R.A.; Van Den Berg, K.R.; Dover, H.E.; Kardell, B.R.; Liby, K.T.; Rockwell, C.E. Differential effects of the Nrf2 activators tBHQ and CDDO-Im on the early events of T cell activation. Biochem. Pharmacol. 2018, 147, 67-76. [CrossRef]

47. DeWitt, J.C.; Blossom, S.J.; Schaider, L.A. Exposure to per-fluoroalkyl and polyfluoroalkyl substances leads to immunotoxicity: Epidemiological and toxicological evidence. J. Expo. Sci. Environ. Epidemiol. 2019, 29, 148-156. [CrossRef]

48. Houck, K.A.; Dix, D.J.; Judson, R.S.; Kavlock, R.J.; Yang, J.; Berg, E.L. Profiling bioactivity of the ToxCast chemical library using BioMAP primary human cell systems. J. Biomol. Screen. 2009, 14, 1054-1066. [CrossRef]

49. Rosen, M.B.; Das, K.P.; Rooney, J.; Abbott, B.; Lau, C.; Corton, J.C. PPAR $\alpha$-independent transcriptional targets of perfluoroalkyl acids revealed by transcript profiling. Toxicology 2017, 387, 95-107. [CrossRef] [PubMed]

50. Ait Bamai, Y.; Goudarzi, H.; Araki, A.; Okada, E.; Kashino, I.; Miyashita, C.; Kishi, R. Effect of prenatal exposure to per- and polyfluoroalkyl substances on childhood allergies and common infectious diseases in children up to age 7 years: The Hokkaido study on environment and children's health. Environ. Int. 2020, 143, 105979. [CrossRef]

51. Salihovic, S.; Lind, L.; Larsson, A.; Lind, P.M. Plasma perfluoroalkyls are associated with decreased levels of proteomic inflammatory markers in a cross-sectional study of an elderly population. Environ. Int. 2020, 145, 106099. [CrossRef] [PubMed]

52. Li, W.; Kong, A.N. Molecular mechanisms of Nrf2-mediated antioxidant response. Mol. Carcinog. 2009, 48, 91-104. [CrossRef] [PubMed]

53. Seelige, R.; Saddawi-Konefka, R.; Adams, N.M.; Picarda, G.; Sun, J.C.; Benedict, C.A.; Bui, J.D. Interleukin-17D and Nrf2 mediate initial innate immune cell recruitment and restrict MCMV infection. Sci. Rep. 2018, 8, 13670. [CrossRef] [PubMed]

54. Gharavi, N.; El-Kadi, A.O. tert-Butylhydroquinone is a novel aryl hydrocarbon receptor ligand. Drug Metab. Dispos. 2005, 33, 365-372. [CrossRef] [PubMed]

55. Schreiber, T.D.; Köhle, C.; Buckler, F.; Schmohl, S.; Braeuning, A.; Schmiechen, A.; Schwarz, M.; Münzel, P.A. Regulation of CYP1A1 gene expression by the antioxidant tert-butylhydroquinone. Drug Metab. Dispos. 2006, 34, 1096-1101. [CrossRef] [PubMed] 
56. Gutiérrez-Vázquez, C.; Quintana, F.J. Regulation of the immune response by the aryl hydrocarbon receptor. Immunity 2018, 48, 19-33. [CrossRef]

57. Boss, A.P.; Freeborn, R.A.; Duriancik, D.M.; Kennedy, R.C.; Gardner, E.M.; Rockwell, C.E. The Nrf2 activator tBHQ inhibits the activation of primary murine natural killer cells. Food Chem. Toxicol. 2018, 121, 231-236. [CrossRef] [PubMed]

58. Zagorski, J.W.; Maser, T.P.; Liby, K.T.; Rockwell, C.E. Nrf2-dependent and-independent effects of tert-butylhydroquinone, CDDO-Im, and $\mathrm{H} 2 \mathrm{O} 2$ in human Jurkat T cells as determined by CRISPR/Cas9 gene editing. J. Pharmacol. Exp. Ther. 2017, 361, 259-267. [CrossRef]

59. Koh, K.; Cha, Y.; Kim, S.; Kim, J. tBHQ inhibits LPS-induced microglial activation via Nrf2-mediated suppression of p38 phosphorylation. Biochem. Biophys. Res. Commun. 2009, 380, 449-453. [CrossRef]

60. Tsatsakis, A.; Petrakis, D.; Nikolouzakis, T.K.; Docea, A.O.; Calina, D.; Vinceti, M.; Goumenou, M.; Kostoff, R.N.; Mamoulakis, C.; Aschner, M.; et al. COVID-19, an opportunity to reevaluate the correlation between long-term effects of anthropogenic pollutants on viral epidemic/pandemic events and prevalence. Food Chem. Toxicol. 2020, 141, 111418. [CrossRef]

61. Punt, A.; Firman, J.; Boobis, A.; Cronin, M.; Gosling, J.P.; Wilks, M.F.; Hepburn, P.A.; Thiel, A.; Fussell, K.C. Potential of ToxCast data in the safety assessment of food chemicals. Toxicol. Sci. 2020, 174, 326-340. [CrossRef]

62. Maffini, M.V.; Neltner, T.G.; Vogel, S. We are what we eat: Regulatory gaps in the United States that put our health at risk. PLoS Biol. 2017, 15, e2003578. [CrossRef] [PubMed]

63. U.S. Food and Drug Administration. Guidance for Industry and Other Stakeholders: Redbook 2000. Toxicological Principles for the Safety Assessment of Food Ingredients. July 2007. Available online: https:/ / www.fda.gov/regulatory-information/searchfda-guidance-documents/guidance-industry-and-other-stakeholders-redbook-2000 (accessed on 15 February 2021).

64. U.S. Food and Drug Administration. Guidance for Industry: Preparation of Food Contact Notifications for Food Contact Substances (Toxicology Recommendations). April 2002. Available online: https:/ / www.fda.gov/regulatory-information/search-fdaguidance-documents / guidance-industry-preparation-food-contact-notifications-food-contact-substances-toxicology (accessed on 15 February 2021).

65. Groh, K.J.; Geueke, B.; Martin, O.; Maffini, M.; Muncke, J. Overview of intentionally used food contact chemicals and their hazards. Environ. Int. 2021, 150, 106225. [CrossRef] [PubMed]

66. Ogungbesan, A.; Neal-Kluever, A.; Rice, P. Exploring the use of current immunological assays for the developmental immunotoxicity assessment of food contact materials. Food Chem. Toxicol. 2019, 133, 110801. [CrossRef]

67. Chappell, G.A.; Britt, J.K.; Borghoff, S.J. Systematic assessment of mechanistic data for FDA-certified food colors and neurodevelopmental processes. Food Chem. Toxicol. 2020, 140, 111310. [CrossRef] [PubMed]

68. Mestas, J.; Hughes, C.C.W. Of mice and not men: Differences between mouse and human immunology. J. Immunol. 2004, 172, 2731-2738. [CrossRef]

69. Shay, T.; Jojic, V.; Rothamel, K.; Puyraimon-Zemmour, D.; Feng, T.; Wakamatsu, E.; Benoist, C.; Koller, D.; Regev, A.; ImmGen Consortium. Conservation and divergence in the transcriptional programs of the human and mouse immune systems. Proc. Natl. Acad. Sci. USA 2013, 110, 2946-2951. [CrossRef]

70. Rockwell, C.E.; Zhang, M.; Fields, P.E.; Klaassen, C.D. Th2 skewing by activation of Nrf2 in CD4+ T cells. J. Immunol. 2012, 188, 1630-1637. [CrossRef] [PubMed]

71. Joint FAO/WHO Expert Committee on Food Additives (JECFA). Safety Evaluation of Certain Food Additives and Contaminants. WHO Food Additives Series 40. World Health Organization, Geneva. 1998. tert-Butylhydroquinone (TBHQ). Available online: http:/ / www.inchem.org/documents/jecfa/jecmono/v040je02.htm (accessed on 15 February 2021). tert-Butylhydroquinone (TBHQ).

72. National Toxicology Program. NTP Toxicology and Carcinogenesis Studies of t-Butylhydroquinone (CAS No. 1948-33-0) in F344/N Rats and B6C3F(1) Mice (Feed Studies). Natl Toxicol Program Tech Rep Ser. 459:1-326. Available online: https: //ntp.niehs.nih.gov/go/tr459 (accessed on 15 February 2021).

73. European Food Safety Authority. Opinion of the Scientific Panel on food additives, flavourings, processing aids and materials in contact with food (AFC) on a request from the Commission related to tertiary-Butylhydroquinone (TBHQ). EFSA J. 2004, 2, 84. [CrossRef]

74. Dalsager, L.; Christensen, N.; Husby, S.; Kyhl, H.; Nielsen, F.; Høst, A.; Grandjean, P.; Jensen, T.K. Association between prenatal exposure to perfluorinated compounds and symptoms of infections at age 1-4 years among 359 children in the Odense Child Cohort. Environ. Int. 2016, 96, 58-64. [CrossRef] [PubMed]

75. Granum, B.; Haug, L.S.; Namork, E.; Stolevik, S.B.; Thomsen, C.; Aaberge, I.S.; van Loveren, H.; Løvik, M.; Nygaard, U.C. Pre-natal exposure to perfluoroalkyl substances may be associated with altered vaccine antibody levels and immune-related health outcomes in early childhood. J. Immunotoxicol. 2013, 10, 373-379. [CrossRef] [PubMed]

76. Averina, M.; Brox, J.; Huber, S.; Furberg, A.S.; Sørensen, M. Serum perfluoroalkyl substance (PFAS) and risk of asthma and various allergies in adolescents. The Tromsø study Fit Futures in Northern Norway. Environ. Res. 2019, 169, 114-121. [CrossRef]

77. Buser, M.C.; Scinicariello, F. Perfluoroalkyl substances and food allergies in adolescents. Environ. Int. 2016, 88, 74-79. [CrossRef] [PubMed]

78. Corsini, E.; Luebke, R.W.; Germolec, D.R.; DeWitt, J.C. Perfluorinated compounds: Emerging POPs with potential immunotoxicity. Toxicol. Lett. 2014, 230, 263-270. [CrossRef] [PubMed]

79. Zhang, Y.; Le, Y.; Bu, P.; Cheng, X. Regulation of Hox and ParaHox genes by perfluorochemicals in mouse liver. Toxicology 2020, 441, 152521. [CrossRef] [PubMed] 
80. Tang, J.; Jia, X.; Gao, N.; Wu, Y.; Liu, Z.; Lu, X.; Du, Q.; He, J.; Li, N.; Chen, B.; et al. Role of the Nrf2-ARE pathway in perfluorooctanoic acid (PFOA)-induced hepatotoxicity in Rana nigromaculata. Environ. Pollut. 2018, 238, 1035-1043. [CrossRef] [PubMed]

81. Liu, W.; Yang, B.; Wu, L.; Zou, W.; Pan, X.; Zou, T.; Liu, F.; Xia, L.; Wang, X.; Zhang, D. Involvement of NRF2 in perfluorooctanoic acid-induced testicular damage in male mice. Biol. Reprod. 2015, 93, 41. [CrossRef] [PubMed]

82. Rosen, M.B.; Lee, J.S.; Ren, H.; Vallanat, B.; Liu, J.; Waalkes, M.P.; Abbott, B.D.; Lau, C.; Corton, J.C. Toxicogenomic dissection of the perfluorooctanoic acid transcript profile in mouse liver: Evidence for the involvement of nuclear receptors PPAR alpha and CAR. Toxicol. Sci. 2008, 103, 46-56. [CrossRef]

83. Rani, A.; Murphy, J.J. STAT5 in cancer and immunity. J. Interferon Cytokine Res. 2016, 36, 226-237. [CrossRef]

84. Bansal, A.; Henao-Mejia, J.; Simmons, R.A. Immune system: An emerging player in mediating effects of endocrine disruptors on metabolic health. Endocrinology 2018, 159, 32-45. [CrossRef]

85. $\mathrm{Ng}$, C.A.; Hungerbuehler, $\mathrm{K}$. Exploring the use of molecular docking to identify bioaccumulative perfluorinated alkyl acids (PFAAs). Environ. Sci. Technol. 2015, 49, 12306-12314. [CrossRef]

86. Li, C.H.; Ren, X.M.; Guo, L.H. Adipogenic activity of oligomeric hexafluoropropylene oxide (perfluorooctanoic acid alternative) through peroxisome proliferator-activated receptor $\gamma$ pathway. Environ. Sci. Technol. 2019, 53, 3287-3295. [CrossRef] [PubMed]

87. Xin, Y.; Ren, X.M.; Wan, B.; Guo, L.H. Comparative in vitro and in vivo evaluation of the estrogenic effect of hexafluoropropylene oxide homologues. Environ. Sci. Technol. 2019, 53, 8371-8380. [CrossRef] [PubMed]

88. Fitzgerald, N.J.M.; Wargenau, A.; Sorenson, C.; Pedersen, J.; Tufenkji, N.; Novak, P.J.; Simcik, M.F. Partitioning and accumulation of perfluoroalkyl substances in model lipid bilayers and bacteria. Environ. Sci. Technol. 2018, 52, 10433-10440. [CrossRef]

89. Nouhi, S.; Ahrens, L.; Campos Pereira, H.; Hughes, A.V.; Campana, M.; Gutfreund, P.; Palsson, G.K.; Vorobiev, A.; Hellsing, M.S. Interactions of perfluoroalkyl substances with a phospholipid bilayer studied by neutron reflectometry. J. Colloid. Interface Sci. 2018, 511, 474-481. [CrossRef] [PubMed]

90. DeWitt, J.C.; Germolec, D.R.; Luebke, R.W.; Johnson, V.J. Associating changes in the immune system with clinical diseases for interpretation in risk assessment. Curr. Protoc. Toxicol. 2016, 67, 18.1.1-18.1.22. [CrossRef] [PubMed]

91. Begley, T.H.; White, K.; Honigfort, P.; Twaroski, M.L.; Neches, R.; Walker, R.A. Perfluorochemicals: Potential sources of and migration from food packaging. Food Addit. Contam. 2005, 22, 1023-1031. [CrossRef]

92. Begley, T.H.; Hsu, W.; Noonan, G.; Diachenko, G. Migration of fluorochemical paper additives from food-contact paper into foods and food simulants. Food Addit. Contam. Part A Chem. Anal. Control. Expo. Risk Assess. 2008, 25, 384-390. [CrossRef]

93. Bradley, E.L.; Read, W.A.; Castle, L. Investigation into the migration potential of coating materials from cookware products. Food Addit. Contam. 2007, 24, 326-335. [CrossRef]

94. Choi, H.; Bae, I.A.; Choi, J.C.; Park, S.J.; Kim, M. Perfluorinated compounds in food simulants after migration from fluorocarbon resin-coated frying pans, baking utensils, and non-stick baking papers on the Korean market. Food Addit. Contam. Part B Surveill. 2018, 11, 264-272. [CrossRef]

95. Elizalde, M.P.; Gomez-Lavin, S.; Urtiaga, A.M. Migration of perfluorinated compounds from paper bag to Tenax ${ }^{\circledR}$ and lyophilised milk at different temperatures. Intern. J. Environm. Anal. Chem. 2019, 98, 1423-1433. [CrossRef]

96. Fengler, R.; Schlummer, M.; Gruber, L.; Fiedler, D.; Weise, N. Migration of Fluorinated Telomer Alcohols (FTOH) from Food Contact Materials into Food at Elevated Temperatures. In Proceedings of the Conference paper presented at 1th International Symposium on Halogenated Persistent Organic Pollutants (POPs)-Dioxin, Brussels, Belgium, 21-25 August 2011; Available online: http:/ / dev.dioxin20xx.org/wp-content/uploads/pdfs/2011/2107.pdf (accessed on 15 February 2021).

97. Gebbink, W.A.; Ullah, S.; Sandblom, O.; Berger, U. Polyfluoroalkyl phosphate esters and perfluoroalkyl carboxylic acids in target food samples and packaging-method development and screening. Environ. Sci. Pollut. Res. Int. 2013, 20, 7949-7958. [CrossRef] [PubMed]

98. Poothong, A.; Boontanon, S.K.; Boontanon, N. Determination of perfluorooctane sulfonate and perfluorooctanoic acid in food packaging using liquid chromatography coupled with tandem mass spectrometry. J. Hazard. Mater. 2012, 205-206, 139-143. [CrossRef] [PubMed]

99. Poweley, C.R.; Michalczyk, M.J.; Kaiser, M.A.; Buxton, W. Determination of perfluorooctanoic acid (PFOA) extractable from the surface of commercial cookware under simulated cooking conditions by LC/MS/MS. Analyst 2005, 130, 1299-1302. [CrossRef]

100. Schlummer, M.; Sölch, C.; Meisel, T.; Still, M.; Gruber, L.; Wolz, G. Emission of perfluoroalkyl carboxylic acids (PFCA) from heated surfaces made of polytetrafluoroethylene (PTFE) applied in food contact materials and consumer products. Chemosphere 2015, 129, 46-53. [CrossRef]

101. Sinclair, E.; Kim, S.K.; Akinleye, H.B.; Kannan, K. Quantitation of gas-phase perfluoroalkyl surfactants and fluorotelomer alcohols released from nonstick cookware and microwave popcorn bags. Environ. Sci. Technol. 2007, 41, 1180-1185. [CrossRef]

102. Still, M.; Schlummer, M.; Gruber, L.; Fiedler, D.; Wolz, G. Impact of industrial production and packaging processes on the concentration of per- and polyfluorinated compounds in milk and dairy products. J. Agric. Food Chem. 2013, 61, 9052-9062. [CrossRef]

103. Xu, Y.; Noonan, G.O.; Begley, T.H. Migration of perfluoroalkyl acids from food packaging to food simulants. Food Addit. Contam. Part A Chem. Anal. Control Expo. Risk Assess. 2013, 30, 899-908. [CrossRef]

104. Yuan, G.; Peng, H.; Huang, C.; Hu, J. Ubiquitous occurrence of fluorotelomer alcohols in eco-friendly paper-made food-contact materials and their implication for human exposure. Environ. Sci. Technol. 2016, 50, 942-950. [CrossRef] 
105. Zabaleta, I.; Blanco-Zubiaguirre, L.; Baharli, E.N.; Olivares, M.; Prieto, A.; Zuloaga, O.; Elizalde, M.P. Occurrence of per- and polyfluorinated compounds in paper and board packaging materials and migration to food simulants and foodstuffs. Food Chem. 2020, 321, 126746. [CrossRef]

106. Jin, Y.N.; Bursley, J.; Dover, H.; Gangur, V.; Rockwell, C.E. The effect of the common food additive tBHQ in OVA-elicited food allergy. J. Immunol. 2018, 200, 104.4.

107. Takeda, M.; Oyama, K.; Kamemura, N.; Kanemaru, K.; Yuasa, K.; Yokoigawa, K.; Oyama, Y. Change in plasma membrane potential of rat thymocytes by tert-butylhydroquinone, a food additive: Possible risk on lymphocytes. Food Chem. Toxicol. 2017, 109, 296-301. [CrossRef]

108. Turley, A.E.; Zagorski, J.W.; Rockwell, C.E. The Nrf2 activator tBHQ inhibits T cell activation of primary human CD4 T cells. Cytokine 2015, 71, 289-295. [CrossRef]

109. Macoch, M.; Morzadec, C.; Génard, R.; Pallardy, M.; Kerdine-Römer, S.; Fardel, O.; Vernhet, L. Nrf2-dependent repression of interleukin-12 expression in human dendritic cells exposed to inorganic arsenic. Free Radic. Biol. Med. 2015, 88, 381-390. [CrossRef] [PubMed]

110. Morzadec, C.; Macoch, M.; Sparfel, L.; Kerdine-Römer, S.; Fardel, O.; Vernhet, L. Nrf2 expression and activity in human T lymphocytes: Stimulation by $\mathrm{T}$ cell receptor activation and priming by inorganic arsenic and tert-butylhydroquinone. Free Radic. Biol. Med. 2014, 71, 133-145. [CrossRef] [PubMed]

111. Zagorski, J.W.; Turley, A.E.; Dover, H.E.; Van Den Berg, K.R.; Compton, J.R.; Rockwell, C.E. The Nrf2 activator, tBHQ, differentially affects early events following stimulation of Jurkat cells. Toxicol. Sci. 2013, 136, 63-71. [CrossRef] [PubMed] 